Marcelo Batista Bonadio

\title{
Tratamento das lesões de edema medular ósseo do joelho pela técnica de subcondroplastia
}

Tese apresentada à Faculdade de Medicina da Universidade de São Paulo para obtenção do título de Doutor em Ciências

Programa de Ciências do Sistema Musculoesquelético

Orientador: Prof. Dr. Marco Kawamura Demange

São Paulo

2019 


\section{Dados Internacionais de Catalogação na Publicaçăo (CIP)}

Preparada pela Biblioteca da

Faculdade de Medicina da Universidade de São Paulo

Creproduçăo autorizada pelo autor

Bonadio, Marcelo Batista

Tratamento das lesōes de edema medular ósseo do

joelho pela técnica de subcondroplastia / Marcelo

Batista Bonadio. -- Săo Paulo, 2019.

Tese (doutorado)--Faculdade de Medicina da

Universidade de São Paulo.

Programa de Ciências do Sistema

Musculoesquelético.

orientador: Marco Kawamura Demange.

Descritores: 1.Artroplastia subcondral 2.Doenças da medula óssea 3.Articulação do joelho 4. Estudos de coortes 5 .Substitutos ósseos 6.Osteoartrite do joelho 7. Imagem por ressonância magnética

USP/FM/DBD-136/19

Responsável: Erinalva da Conceiçăo Batista, CRB-8 6755 


\section{DEDICATÓRIA}

Aos meus pais que são responsáveis pela pessoa que sou hoje. Minha mãe Marilena que sempre se empenhou em minha educação e é um exemplo da busca constante ao conhecimento. Meu pai João, que é meu maior exemplo de dedicação ao trabalho com ensinamentos diários na boa prática da medicina.

A minha esposa Renata, minha companheira eterna de todos os momentos, cujo convívio me torna uma pessoa melhor e mais feliz a cada dia.

Ao meu irmão Heitor que é meu parceiro incondicional e meu maior e mais antigo amigo. 


\section{AGRADECIMENTOS}

Ao Prof. Marco Kawamura Demange, meu orientador, pelo ensinamento, inspiração e confiança constante.

Ao Prof. Gilberto Luís Camanho, Professor Titular do Departamento de Ortopedia e Traumatologia da Faculdade de Medicina da Universidade de São Paulo, pelo apoio e por ter me orientado inicialmente na confecção desta tese.

Aos Professores Olavo Pires de Camargo e Tarcísio Eloy Pessoa de Barros Filho, Professores Titulares do Departamento de Ortopedia e Traumatologia da Faculdade de Medicina da Universidade de São Paulo, pela possibilidade de aprimorar minha formação acadêmica.

Aos Drs. Alípio Gomes Ormond Filho e Paulo Victor Partezani Helito, pela amizade e ajuda nas avaliações dos exames de imagem.

Aos Drs. Riccardo Gomes Gobbi, Roberto Freira da Mota e Albuquerque e Leandro Einjsman pelos valiosos conselhos para o aprimoramento desta tese.

À Profa. Márcia Uchoa de Rezende, Prof. José Ricardo Pécora, Dr. Fábio Janson Angelini, Dr. Luís Eduardo Passarelli Tírico e Dr. Camilo Partezani Helito pelo convívio no grupo de joelho, aprendizado e apoio.

Ao Dr. Marco Antônio Gonçalves Pontes Filho, pela ajuda na avaliação e coleta de dados dos pacientes.

À Dra. Renata Rodrigues da Cunha Colombo Bonadio, pelo suporte e pelo auxílio com a análise estatística.

Aos amigos Tales Mollica Guimarães, Pedro Nogueira Giglio e Marcel Faraco Sobrado, pela amizade, pelo suporte e por terem ao longo dos anos contribuído muito para a confecção desta tese. 
A todos os colegas médicos e residentes que passaram pelo grupo de joelho e de alguma forma participaram de uma das fases deste estudo.

À Tânia Fernanda Cardoso pela ajuda imprescindível.

Às secretarias Tânia Borges e Rosana Moreno do programa de pós-graduação.

Às bibliotecárias Camila Gomes da Rocha Agostini e Andressa da Costa Santos Souza.

À empresa LAS Brasil pelo apoio e doações de materiais para a realização deste estudo.

A todos os pacientes que participaram desta tese, pela confiança e pela oportunidade de cuidar deles. 


\section{NORMALIZAÇÃO ADOTADA}

Esta dissertação ou tese está de acordo com as seguintes normas, em vigor no momento desta publicação:

Referências: adaptado de International Committee of Medical Journals Editors (Vancouver).

Estrutura e apresentação: Universidade de São Paulo. Faculdade de Medicina. Divisão de Biblioteca e Documentação. Guia de apresentação de dissertações, teses e monografias. Elaborado por Anneliese Carneiro da Cunha, Maria Julia de A. L. Freddi, Maria F. Crestana, Marinalva de Souza Aragão, Suely Campos Cardoso, Valéria Vilhena. 3a ed. São Paulo: Divisão de Biblioteca e Documentação; 2011.

Abreviaturas dos títulos dos periódicos de acordo com List of Journals Indexed in Index Medicus. 


\section{SUMÁRIO}

Lista de Símbolos, Abreviaturas e Siglas

Lista de Figuras

Lista de Tabelas

Lista de Gráficos

Resumo

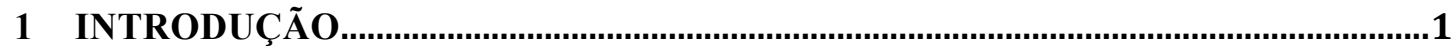

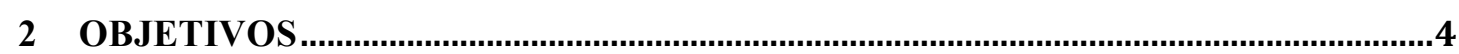

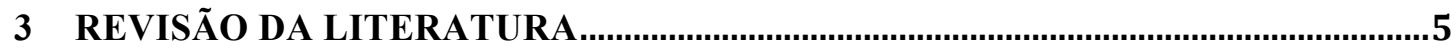

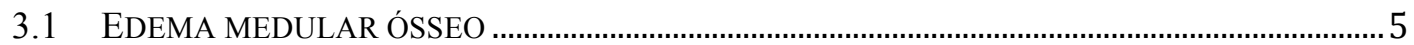

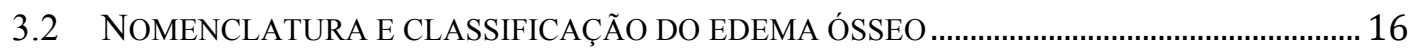

3.3 SUBCONDROPLASTIA ............................................................................................ 18

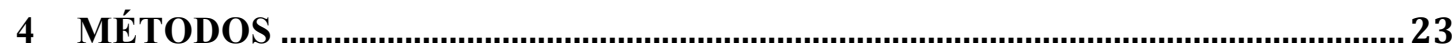

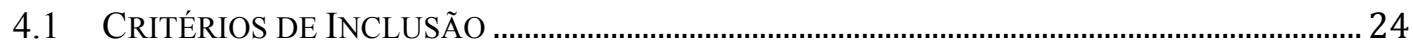

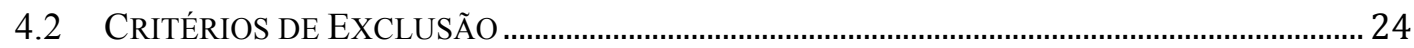

4.3 AVALIAÇÃO INICIAL ..................................................................................................... 25

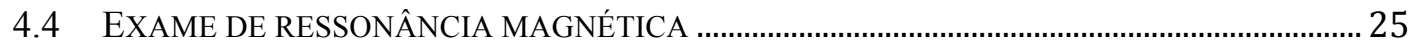

4.5 AVALIAÇÃO RADIOGRÁFICA E RESSONÂNCIA MAGNÉTICA.............................................. 26

4.6 AVALIAÇÃO CLÍNICA E FUNCIONAL …………................................................................. 27

4.7 ACOMPANHAMENTO DOS PACIENTES ……….................................................................. 27

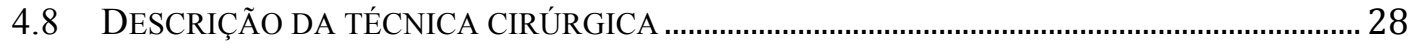

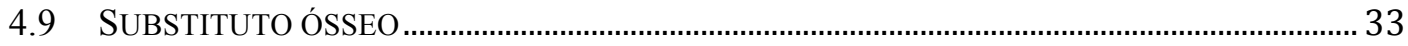

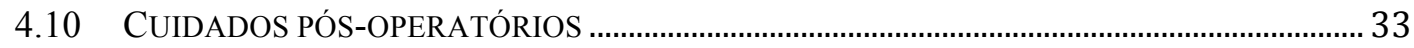

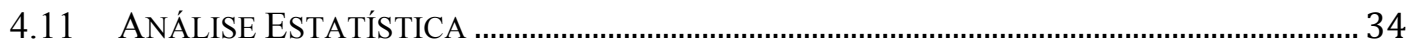

5 RESULTADOS

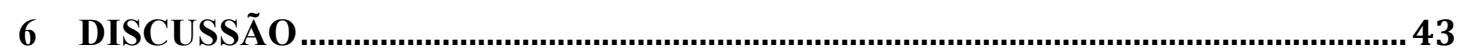

7 CONCLUSÃO

8 ANEXOS

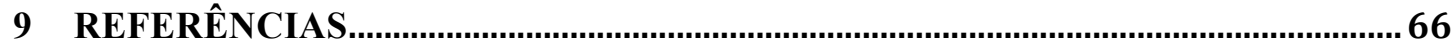




\section{Listas de Símbolos}

$\begin{array}{ll}\% & \text { por cento } \\ \pm & \text { mais ou menos } \\ < & \text { menor que } \\ = & \text { igual a } \\ > & \text { maior que } \\ \mathrm{cm} & \text { centímetro } \\ \mathrm{G} & \text { Gauge } \\ \mathrm{g} & \text { grama } \\ \mathrm{mg} & \text { miligrama } \\ \mathrm{mm} & \text { milímetro } \\ \mathrm{Mpa} & \text { Megapascal } \\ \mathrm{T} & \text { Tesla }\end{array}$

Listas de Abreviaturas

et al.

e outros

\section{Listas de Siglas}

CAPPESQ

Comissão de ética para análise de projetos de pesquisa

EVA

escala visual analógica

HCFMUSP

Hospital das Clínicas da Universidade de São Paulo

IKDC

International Knee Documentation Commitee

IMC

índice de massa corpórea

IOTHCFMUSP

Instituto de Ortopedia e Traumatologia do Hospital das Clínicas da Universid de São Paulo

KOOS

Injury and Osteoarthritis Outcomes Score

MOST

Multicenter Osteoartrhitis

OR

odds ratio / razão de chance

PCR

Proteína C Reativa

TC

tomografia computadorizada

USP

Universidade de São Paulo 


\section{Listas de Figuras}

Figura 1 Corte coronal de exame de ressonância magnética de joelho direito em ponderação T2, ilustrando um edema medial ósseo no côndilo femoral medial, correspondente à área de coloração branca apontada pela seta

Figura 2 Planejamento pré-operatório na imagem da ressonância magnética a) Corte coronal de ressonância magnética de joelho esquerdo em ponderação T2 com edema medular ósseo no côndilo femoral medial; b) Corte coronal com mapeamento da área do edema (linha laranja) e ponto alvo para injeção (asterisco em laranja); c) Corte coronal com duas opções de planejamento de trajetória de introdução da cânula (setas amarelas); d) Corte sagital de ressonância magnética de joelho esquerdo em ponderação T2 com edema medular ósseo no côndilo femoral medial; e) Corte sagital com mapeamento da área do edema (linha laranja) e ponto alvo para injeção (asterisco em laranja); f) Corte coronal com duas opções de planejamento de trajetória para introdução da cânula (setas amarelas)

Figura 3 a) Fotografia com visão anterior de joelho direito com cânula sobre o joelho para programação de trajeto para introdução da cânula; b) Imagem de fluoroscopia intraoperatória em incidência anteroposterior do planejamento do trajeto da cânula de superolateral para inferomedial, com alvo no côndilo femoral medial

Figura 4 a) Fotografia com visão lateral do joelho direito com cânula sobreposta para programação do trajeto para introdução da cânula; b) Imagem de fluoroscopia em incidência de perfil do planejamento do trajeto para introdução da cânula

Figura 5 Fotografia em visão lateral de joelho direito com linha desenhada no trajeto planejado para introdução de cânula posicionada no seu ponto de entrada, conforme direção do planejamento

Figura 6 Imagem de fluroscopia intraoperatória em incidência anteroposterior de joelho direito, após retirada da cânula, com possível visualização do substituto ósseo injetado na área de mais radiopaca no côndilo femoral medial circulada em amarelo

Figura 7 Radiografias em incidência anteroposterior do joelho esquerdo do paciente de identificação 3 , que apresentou extravasamento do enxerto na região supracondiliana medial a) Radiografia imediatamente após a cirurgia com seta em amarelo apontando a imagem do material extravasado; b) Radiografia após 48 semanas de seguimento com reabsorção do material extravasado 


\section{Lista de Tabelas}

Tabela 1 Dados clínicos e demográficos dos pacientes ................................. 36

Tabela 2 Média das avaliações clínicas pela escala de KOOS dentro dos seus subgrupos de sintomas, dor, função diária, função esportiva e qualidade de vida; escala de IKDC subjetivo e EVA de dor

Tabela 3 Média das avaliações da qualidade de vida pela escala SF-36v1 dentro dos seus subgrupos de capacidade funcional, aspectos físicos, dor, estado geral de saúde, vitalidade, aspectos sociais, aspectos emocionais e saúde mental

Tabela 4 Progressão da osteoartrite pela classificação de Kellgren-Lawrence e diferença das escalas de IKDC e EVA de dor do período préoperatório para o seguimento final com 48 semanas

Tabela 5 Avaliações dos exames de ressonância magnética pré-operatórios e após as 48 semanas de seguimento 


\section{Lista de Gráficos}

Gráfico 1 Evolução da média da escala de KOOS em seus diferentes subgrupos de sintomas, dor, função diária, função esportiva e qualidade de vida, no período de seguimento

Gráfico 2 Evolução da média da escala de IKDC Subjetivo no período de seguimento

Gráfico 3 Evolução da média da escala visual analógica de dor no período de seguimento

Gráfico 4 Porcentagem de pacientes com melhora da escala de IKDC subjetivo ao final do seguimento

Gráfico 5 Porcentagem de pacientes com melhora maior que 2 pontos pela EVA de dor ao final do seguimento 


\section{RESUMO}

Bonadio MB. Tratamento das lesões de edema medular ósseo no joelho pela técnica de subcondroplastia [tese]. São Paulo: Faculdade de Medicina, Universidade de São Paulo; 2019.

INTRODUÇÃO: O edema medular ósseo pode ser encontrado em diversas doenças do joelho e existe ainda grande controvérsia quanto à sua classificação e nomenclatura na literatura, principalmente, em vista dos estudos mais recentes, a partir do ano de 2000, quando a repercussão clínica de tais alterações de imagens de ressonância magnética começaram a ser melhor avaliadas. Estudos demonstraram a correlação do edema ósseo com a dor e a progressão da osteoartrite. Um novo método cirúrgico desenvolvido para o tratamento dessas lesões é denominado subcondroplastia e consiste na injeção de substituto ósseo pastoso no local do edema medular ósseo. O objetivo do presente trabalho é avaliar a técnica de subcondroplastia no Brasil quanto a sua aplicabilidade e os resultados no tratamento do edema medular ósseo. MÉTODOS: Foram incluídos pacientes com idade entre 40 e 85 anos, com dor no joelho há pelo menos 6 meses, associada à ressonância magnética com lesão de hipersinal em ponderação de T2 na tíbia ou fêmur. Os pacientes foram avaliados segundo a escala visual analógica de dor e pela escala de KOOS, IKDC subjetivo e SF36, uma semana antes da cirurgia e com 1, 3, 6, 12, 24 e 48 semanas após. Também foi realizada avaliação por imagem do joelho afetado com radiografia e ressonância magnética, sendo tais exames realizados no pré-operatório e após 48 semanas da cirurgia. A subcondroplastia foi realizada com técnica desenvolvida para o preenchimento da área de lesão óssea medular, guiada por fluoroscopia, com 
substituto ósseo em pasta à base de fosfato de cálcio. RESULTADOS: O preenchimento foi realizado com sucesso em 20 joelhos, sendo 11 lesões no côndilo femoral medial e 12 no planalto tibial medial. A avaliação pela escala de KOOS apresentou uma melhora significativa durante o seguimento na avaliação de sintomas ( $<<0,001)$, dor $(p<0,001)$, função diária $(p<0,001)$, função esportiva $(p=0,006)$ e qualidade de vida $(p<0,001)$. As avaliações pelas escalas do IKDC subjetivo $(\mathrm{p}<0,001)$ e dor pela EVA $(\mathrm{p}<0,001)$ também apresentaram melhora significativa. $\mathrm{Na}$ avaliação da qualidade de vida pela escala SF-36, os critérios de capacidade funcional ( $<<0,001)$, aspectos físicos $(p<0,001)$, estado geral de saúde $(p=0,015)$, vitalidade ( $p=0,017)$, aspectos sociais $(\mathrm{p}<0,003)$, aspectos emocionais $(\mathrm{p}<0,001)$ e saúde mental $(p=0,019)$ apresentaram melhora significativa e apenas o critério de dor $(p=0,398)$ não obteve melhora significativa. A escala radiográfica de Kellgren-Lawrence ao final do seguimento foi significativamente pior que a pontuação pré-operatória $(p=0,025)$. Doze ressonâncias magnéticas realizadas após 48 semanas de seguimento foram avaliadas, com seis pacientes apresentando redução do edema. A impacção estava pior em 5 joelhos, não houve alteração em 6 joelhos e em apenas 1 houve redução da impacção. Todos os pacientes conseguiram deambular, sem apoio adicional, já no primeiro dia após o procedimento. Como complicações, dois pacientes apresentaram extravasamento de enxerto para partes moles. CONCLUSÃO: A técnica de subcondroplastia é segura, apresenta melhora rápida e sustentada de dor e desempenho funcional dos pacientes em um seguimento de 48 semanas.

Descritores: Artroplastia subcondral; Doenças da medula óssea; Articulação do joelho; Estudos de coortes; Substitutos ósseos; Osteoartrite do joelho; Imagem por ressonância magnética. 


\begin{abstract}
Bonadio MB. Treatment of bone marrow edema lesions of the knee with subchondroplasty technique [thesis]. São Paulo: "Faculdade de Medicina, Universidade de São Paulo"; 2019.
\end{abstract}

INTRODUCTION: Bone marrow edema can be found in several pathologies of the knee and there is still great controversy regarding classification and nomenclature in the literature, especially in view of the most recent studies since the year 2000, when the clinical repercussion of such magnetic resonance imaging began to be better evaluated. Studies have shown the correlation of bone edema with pain and osteoarthritis progression. A new surgical method developed for the treatment of these lesions is called subchondroplasty and consists of the injection of a paste substitute at the site of bone marrow edema. The aim of the present study was the development of the subchondroplasty technique in Brazil to evaluate its applicability and results in the treatment of bone marrow edema. METHODS: We included patients aged 40 to 85 years, with pain in the knee for at least 6 months, associated with increased uptake MRI lesion on T2 weighting in the tibia or femur. The patients were evaluated according to the visual analogue pain scale and the KOOS, subjective IKDC and SF36 scales one week before surgery and at 1, 3, 6, 12, 24 and 48 weeks after surgery. We also performed image evaluation of the affected knee with radiography and MRI, which were performed preoperatively and after 48 weeks of surgery. The subchondroplasty was performed using a technique developed to fill the area of bone marrow lesion, guided by fluoroscopy, with a bone substitute in a paste 
based on calcium phosphate. RESULTS: The filling was successfully performed on 20 knees, with 11 lesions on the medial femoral condyle and 12 on the medial tibial plateau. The KOOS score showed a significant improvement during the evaluation of symptoms $(p<0.001)$, pain $(p<0.001)$, daily function $(p<0.001)$, sports function $(\mathrm{p}=0.006)$ and quality of life $(\mathrm{p}<0.001)$. Evaluations by the subjective IKDC scales $(p<0.001)$ and pain by the VAS $(p<0.001)$ also showed significant improvement. In the evaluation of the SF-36 quality of life the criteria of functional capacity $(p<0.001)$, physical aspects $(p<0.001)$, general health status $(p=0.015)$, vitality $(p=0.017)$, social aspects $(p<0.003)$, emotional aspects $(p<0.001)$ and mental health $(p=0.019)$ presented significant improvement, and only the pain criteria $(\mathrm{p}=0.398)$ showed no significant improvement. The Kellgren-Lawrence scale at the end of the follow-up was significantly worse than the preoperative score $(p=0.025)$. Twelve magnetic resonances performed after 48 weeks of follow-up were evaluated, with six patients presenting with edema reduction. The impaction was worse in 5 knees, in 6 there was no alteration and in 1 there was reduction of impaction. All patients were able to walk, without additional support, on the first day after the procedure. As complications, two patients presented extravasation of graft to soft parts. CONCLUSION: The subchondroplasty technique is safe and presents rapid and sustained improvement of pain and functional performance of patients at a 48-week follow-up.

Descriptors: Arthroplasty, subchondral; Bone marrow diseases; Knee joint; Cohort studies; Bone substitutes; Osteoarthritis, knee; Magnetic resonance imaging. 


\section{INTRODUÇÃO}

Edema medular ósseo é o termo genérico mais classicamente utilizado para descrever uma lesão de alto sinal identificada nas ponderações sensíveis a líquido na ressonância magnética. ${ }^{1-3} \mathrm{O}$ termo foi descrito inicialmente em 1988 durante a avaliação de 10 pacientes com osteoporose transitória do quadril ou do joelho que apresentavam baixo sinal em T1 e alto sinal em T2 na medular óssea, cujas biópsias excluíram necrose isquêmica e metástases. Acreditando que as alterações na ressonância magnética representavam aumento transitório no conteúdo aquoso medular (edema), na falta de melhor nomenclatura e para enfatizar o caráter genérico da condição, propuseram a denominação: "Síndrome do edema transitório da medula óssea". 4

Zanetti et al. ${ }^{5}$, em 2000, realizaram exame de ressonância magnética, 1 a 4 dias antes da cirurgia, em 16 pacientes submetidos à artroplastia total do joelho, e correlacionaram os achados com a avaliação histopatológica. Com isso, foi demonstrado que a anormalidade de sinal na ressonância magnética, até então denominada como edema ósseo, em joelhos com osteoartrite, representa na verdade uma série de anormalidades histológicas (tecido normal, necrose da medular óssea, trabéculas necróticas ou remodeladas, fibrose, edema e hemorragia), sendo que o edema propriamente dito não é o constituinte principal.

O edema medular ósseo pode ser encontrado em diversas patologias e condições do joelho como traumas, tumores, osteonecroses secundárias, imobilizações, síndromes de edema transitório e osteoartrite ${ }^{2,3,6-9}$. Existe ainda uma grande controvérsia quanto à classificação e nomenclatura na literatura, principalmente, em 
vista dos estudos mais recentes a partir do ano de 2000, quando a repercussão clínica das alterações de imagens em ressonância magnética começaram a ser melhor avaliadas.

Estudos demonstraram a correlação do edema ósseo com a dor, a progressão da osteoartrite, as alterações de alinhamento dos membros inferiores, o peso e o perfil lipídico dos pacientes. ${ }^{10-30}$ Tais achados associados aos estudos histológicos das áreas de edema medular ósseo levaram ao reconhecimento de uma condição de insuficiência do osso subcondral. Essa fratura de insuficiência ocorre geralmente associada a lesões degenerativas da articulação com a presença de lesões do menisco e/ou cartilagem. ${ }^{2,31-34}$ Sendo assim, o alto sinal encontrado nessas situações é por vezes denominado como lesão óssea medular (bone marrow lesion), uma vez que se trata de uma lesão estrutural do osso subcondral e não um edema da região.

Tais resultados trouxeram o questionamento sobre a necessidade e indicação de tratamentos para os edemas medulares ósseos. Entre as diversas propostas de tratamento, o tratamento conservador se baseia principalmente na restrição de carga no membro afetado associado ao uso de anti-inflamatórios e analgésicos, por um período de 3 a 8 meses, conforme sintomatologia e controle radiográfico., ${ }^{2,35}$ Outras linhas de tratamento não cirúrgico propuseram o uso de fármacos como a prostaciclina e o bisfosfonato. ${ }^{36-39}$

A prostaciclina é um vasodilatador que busca uma melhor perfusão de tecidos com irrigação comprometida. A droga também reduz a permeabilidade capilar, inibe a agregação plaquetária e reduz a concentração de radicais livres. Porém, o efeito específico responsável pela melhora da dor na lesão medular óssea não é conhecido. A eficácia da prostaciclina no tratamento das lesões medulares ósseas foi demonstrada 
em alguns estudos de curto seguimento ${ }^{36,37}$, porém com maus resultados em estágios mais avançados. ${ }^{40}$

A segunda droga proposta para o tratamento do edema ósseo, o bisfosfonato, inibe a atividade dos osteoclastos e reduz a reabsorção óssea. O objetivo do uso dessa medicação é evitar o colapso do osso subcondral, decorrente da reabsorção óssea local, causada pela reação à fratura de insuficiência. Dessa forma, a droga permitiria um melhor suporte estrutural até que o processo regenerativo local formasse uma estrutura óssea nova e suficiente para o suporte da carga. Os resultados de estudos clínicos são controversos. Meier et al. ${ }^{39}$ não identificaram diferença significativa entre ibandronato e o placebo no único estudo clínico randomizado e duplo cego. Porém, outros estudos já apresentaram benefícios clínicos e radiográficos no uso da droga. ${ }^{38}$

Um novo método de tratamento cirúrgico para essas lesões foi então desenvolvido com o objetivo de estabilizar mecanicamente a lesão e estimular a recuperação do trabeculado ósseo local. A técnica chamada de subcondroplastia consiste na injeção de substituto ósseo pastoso no local do edema medular ósseo que, uma vez aplicado, passa por um processo endotérmico de cristalização com enrijecimento do composto, que adquire rigidez capaz de auxiliar no suporte mecânico da região. O substituto ósseo possuiu porosidades de diferentes diâmetros, funcionando como um arcabouço estruturado para a incursão de vasos sanguíneos e tecido ósseo neoformado, tendo assim propriedade osteocondutora. O mesmo também é absorvido de forma gradativa, em uma velocidade que permita a regeneração óssea.

Resultados clínicos iniciais das primeiras séries de casos apresentam uma melhora significativa da dor e função dos pacientes submetidos à subcondroplastia. Não existia até o início do presente estudo a disponibilidade dessa técnica no Brasil. Dessa forma, a motivação do presente trabalho foi a avaliação da técnica de subcondroplastia no 
Brasil visando sua aplicabilidade e os resultados no tratamento do edema medular ósseo.

\section{OBJETIVOS}

O objetivo primário desta tese é:

1- Avaliar a eficácia da técnica de subcondroplastia no tratamento de pacientes com edema medular ósseo no joelho, pela avaliação da melhora da dor e da função, com seguimento mínimo de 48 semanas.

Os objetivos secundários desta tese são:

1- Avaliar a segurança e a viabilidade técnica da subcondroplastia no joelho,

2- Avaliar o aspecto da ressonância magnética com enfoque na progressão da degeneração do osso subcondral. 


\section{REVISÃO DA LITERATURA}

\subsection{Edema medular ósseo}

Wilson et al. ${ }^{41}$, em 1988, avaliam 10 pacientes com dor no quadril ou joelho, com radiografias sem alterações ou com osteopenia inespecífica. Todos os pacientes apresentam aumento de captação na cintilografia da articulação acometida. O exame de ressonância magnética, das áreas afetadas, identifica um padrão de baixo sinal na ponderação de T1 e alto sinal na ponderação em T2. Biópsias realizadas em 4 pacientes excluem processo necrótico ou metastático. Os autores na época acreditam que as alterações de imagem decorrem de um aumento de água na medular óssea local, propondo pela primeira vez o termo "Síndrome de edema ósseo transitório".

Bergman et al. $^{42}$, em 1994, pela primeira vez realizam uma correlação entre as lesões de edema ósseo encontradas nas ressonâncias de pacientes com osteoartrite com a avaliação histológica. O osso ressecado durante a artroplastia total de joelho de nove pacientes é avaliado histologicamente, sendo encontrada uma correlação das áreas de edema ósseo com áreas de substituição da gordura medular por um tecido fibroso, também associadas a uma região mais focal de espessamento do trabeculado ósseo.

Yamamoto e Bullough ${ }^{33}$, em 2000, avaliam a histologia de 14 joelhos com o diagnóstico clínico e radiológico de osteonecrose primária. Pela análise histológica, os pacientes são divididos em três grupos: o grupo 1 com fratura subcondral sem evidência de necrose; o grupo 2 com fratura subcondral associada à necrose focal que se limitava à área entre a linha de fratura e a superfície articular; o grupo 3 com 
achados indeterminados devido ao desprendimento da área da superfície articular. Os autores observam que a progressão nestes três grupos acompanham a progressão na escala radiográfica de Koshino ${ }^{43}$, sendo que todos os joelhos no grupo 1 estão no grau dois da classificação radiográfica, todos no grupo 2 estão no grau três e aqueles no grupo 3 estão no grau três ou quatro. Baseados nesses achados e nas características histológicas, os autores propõem que o evento inicial da osteonecrose primária do joelho é a fratura de insuficiência.

Zanetti et al. ${ }^{5}$, em 2000, também realizam uma avaliação histológica das áreas de edema ósseo após a artroplastia total de joelho, encontrando nas áreas de edema uma maior presença de necrose, fibrose da medular e alterações do trabeculado, quando comparadas às áreas controles, sem alteração de sinal na ressonância magnética. A presença de edema não apresenta diferença significativa.

Felson et al. ${ }^{14}$ em 2001 encontram, entre pacientes com osteoartrite, uma maior prevalência $(\mathrm{p}<0,001)$ de lesões de edema ósseo naqueles com dor $(77,5 \%)$ quando comparados aos pacientes sem dor $(30,0 \%)$. A diferença também é significativa quando avaliada a presença de grandes edemas ósseos, presentes em 35,9\% dos pacientes com dor e em apenas $2,0 \%$ dos pacientes sem dor $(\mathrm{p}<0,0001)$.

Felson et al. $^{44}$, em 2003, realizam estudo de seguimento da história natural da osteoartrite em 256 pacientes. Nesse estudo, foi observada uma maior prevalência de edema ósseo no compartimento medial em pacientes com um alinhamento do membro varo e maior prevalência no compartimento lateral em pacientes com alinhamento valgo. A correlação da presença do edema ósseo com a maior progressão da osteoartrite é também evidenciada, avaliada pela redução do espaço articular na radiografia, mesmo após o ajuste pelo alinhamento do membro. Pacientes com edema 
ósseo apresentam uma chance 6,5 vezes maior de progressão da osteoartrite quando no compartimento medial e 6,0 vezes maior quando no compartimento lateral.

Sowers et al. ${ }^{27}$, em 2003, avaliam a ressonância magnética de 120 mulheres com idade entre 35 e 55 anos, sendo estas divididas igualmente em quatro grupos conforme a presença de osteoartrite e dor (Grupo 1: osteoartrite e dor; Grupo 2: osteoartrite sem dor; Grupo 3: sem osteoartrite com dor; e, Grupo 4: sem dor e sem osteoartrite). A presença de edema ósseo e lesão da cartilagem são avaliadas. A presença de algum edema ósseo na imagem da ressonância magnética é semelhante entre os 4 grupos, porém lesões maiores que $1 \mathrm{~cm}$ de diâmetro apresentam uma prevalência maior entre os pacientes do grupo 1.

Lo et al. $^{22}$, em 2005, correlacionam a razão entre a densidade óssea do compartimento medial e lateral (razão M:L) do joelho com a presença de edema ósseo em cada um dos compartimentos. Pacientes que manifestam edema ósseo no compartimento medial apresentam uma razão M:L maior (maior densidade no compartimento medial), enquanto pacientes com lesões no compartimento lateral apresentam uma razão M:L menor (maior densidade no compartimento lateral). Tais dados sugerem a relação de um aumento da densidade óssea nas lesões de edema ósseo, assim como sugerem uma relação de tais lesões com a transmissão de carga na articulação.

Hunter et al. $^{18}$, em 2006, avaliam a ressonância magnética de 217 pacientes, repetindo o exame com 15 e 30 meses de seguimento. Durante o seguimento, 99\% das lesões de edema ósseo não se alteram ou aumentam. Os compartimentos com a maior presença de edema ósseo apresentam o maior índice de perda de cartilagem no período e um aumento do edema ósseo é fortemente correlacionado com uma piora nas escalas de avaliação da superfície condral. A progressão ou surgimento de novas 
lesões de edema ósseo ocorrem mais frequentemente em pacientes com alteração do alinhamento do membro.

Kijowski et al. ${ }^{19}$, em 2006, avaliam a presença de edema ósseo na ressonância magnética de 132 pacientes, correlacionando estas com os achados de inspeção artroscópica da superfície condral. Lesões condrais de maior grau apresentam uma maior prevalência de edemas ósseos assim como uma associação com uma maior profundidade e área do edema.

Felson et al. ${ }^{16}$, em 2007, realizam estudo prospectivo com seguimento de 15 meses para avaliação da relação entre o edema ósseo e a dor de pacientes com osteoartrite. A prevalência de aumento do edema ósseo durante o seguimento é de $49,1 \%$ em joelhos com dor e de $26,8 \%$ em joelhos sem dor $(\mathrm{p}<0,001)$. Além disso, a associação entre o aumento do edema ósseo e a dor é ainda mais significativa quando considerados os aumentos maiores que dois pontos na Whole-organ MRI Score. Os autores concluem que existe uma relação entre o aumento do edema na ressonância magnética e a dor.

Kornaat et al. ${ }^{45}$, em 2007, realizam estudo prospectivo de 2 anos avaliando a evolução do edema ósseo em pacientes com osteoartrite. Um total de 182 pacientes são avaliados e 136 (75\%) têm algum edema ósseo na ressonância magnética. Em 54 (40\%) pacientes há aumento do edema ósseo, em 27 (20\%) pacientes há redução do edema ósseo e em 9 (7\%) pacientes não há alteração. As alterações observadas não apresentam relação com a escala de Western Ontario and McMaster Universities Osteoarthritis(WOMAC) quanto à dor ou função.

Guymer et al. ${ }^{17}$, em 2007, avaliam a ressonância magnética do joelho dominante de 176 mulheres assintomáticas e sem história de trauma no joelho ou clínica de osteoartrite. Uma prevalência de $13,1 \%$ de edema ósseo é encontrada, sendo 7,4\% de 
edema ósseo grande (maior que um quarto do compartimento acometido). O compartimento medial é o mais acometido, com prevalência de $9,1 \%$, enquanto o lateral é de 4,0\%. Fatores de risco independentes para a presença de edema ósseo são: peso, índice de massa corpórea (IMC), perda de cartilagem e área óssea do planalto tibial. Os autores concluem que a presença do edema ósseo está associada a fatores de risco e alterações estruturais iniciais da osteoartrite.

Baranyay et al. $^{10}$, em 2007, realizam estudo com avaliação de ressonância magnética de 297 pacientes assintomáticos e sem história prévia de trauma no joelho. Trinta e nove (13\%) pacientes apresentam edema ósseo. Os seguintes itens apresentam uma correlação positiva com a presença de edema ósseo: lesão condral em compartimentos medial e lateral, maior idade, maior peso, maior área óssea do planalto tibial e gênero masculino.

Kröner et al. $^{46}$, em 2007, avaliam o efeito da cirurgia de osteotomia tibial proximal valgizante, no edema medular ósseo do compartimento medial. Em uma série de casos com 26 pacientes, os autores encontram uma redução no volume do edema medular ósseo do compartimento medial e uma correlação da redução do edema com a melhora clínica dos pacientes pela escala da Associação Japonesa de Ortopedia. O estudo também evidencia que os pacientes com maior correção do eixo anatômico obtêm uma maior redução no volume do edema ósseo e uma melhora clínica mais expressiva.

Raynauld et al. $^{23}$, em 2008, avaliam a ressonância magnética de 107 pacientes com osteoartrite com um seguimento de 24 meses, sendo que destes, 71 pacientes apresentam edema ósseo no início do estudo. No período do estudo, não é observada diferença significativa no tamanho das lesões. Os resultados mostram correlação independente entre a mudança do tamanho do edema ósseo e a perda do volume de 
cartilagem no côndilo femoral medial. É importante salientar que os pacientes incluídos nesse estudo fazem parte de um estudo maior para avaliação do efeito da utilização via oral de bisfosfonatos na osteoartrite do joelho, o que pode ter influenciado a evolução do edema ósseo e da osteoartrite.

Scher et al. $^{26}$, em 2008, realizam estudo retrospectivo com avaliação da ressonância magnética de pacientes com osteoartrite, com seguimento mínimo de 3 anos, no qual demonstram que os pacientes com edema ósseo apresentam um risco 8,95 vezes maior de serem submetidos à artroplastia total do joelho se comparados a pacientes sem edema ósseo. Os pacientes com um edema ósseo de padrão global (acometendo todo o côndilo femoral ou tibial) apresentam um risco 5,45 vezes maior que pacientes com edema focal, edema cístico ou sem edema e 13,04 vezes maior quando comparado apenas a pacientes sem edema. A divisão em diferentes padrões do edema ósseo objetiva uma melhor definição dessas lesões na osteoartrite, para compreensão das correlações clínicas.

Davies-Tuck et al. ${ }^{11}$, em 2009, avaliam a história natural do edema ósseo durante o período de 2 anos, com o seguimento da ressonância magnética de 271 pacientes assintomáticos e sem apresentação clínica de osteoartrite. Uma prevalência de edema ósseo de $14 \%$ é encontrada. IMC elevado $(\mathrm{OR} 1,15)$ e o desenvolvimento de dor durante o período do estudo (OR 4,2) são associados com uma maior presença do edema. Nesse estudo, não é encontrada associação com idade ou gênero.

Romer et al. $^{24}$, em 2009, avaliam a evolução do edema ósseo e a relação com a perda da cartilagem em pacientes com osteoartrite ou com risco para doença. Trezentos e noventa e cinco joelhos são incluídos do estudo Multicenter Osteoarthritis (MOST). Comparados aos joelhos que mantêm o edema ósseo estável, o risco de progressão da degeneração condral é 2,8 vezes maior naqueles com 
progressão do edema ósseo e 3,5 vezes maior em joelhos com novas lesões. Nos joelhos com regressão do edema, o ritmo de progressão da osteoartrite é semelhante ao grupo de referência.

Hunter et al. ${ }^{47}$, em 2009 , estudam peças ressecadas a partir do corte tibial da artroplastia de pacientes com edema ósseo. A avaliação realizada com microtomografia das peças demonstra que as áreas de edema ósseo apresentam uma maior fração de volume ósseo, menor densidade mineral, maior espessura do trabeculado ósseo e maior espaço entre as trabéculas.

Unay et al. ${ }^{29}$, em 2009, realizam estudo para avaliar a evolução de edema ósseo em ressonância magnética de pacientes sem osteoartrite, durante o período de um ano. Pacientes com lesões meniscais ou com lesão condral grau 3 ou maior são excluídos desse trabalho. Os pacientes são instruídos a usar muletas nas seis primeiras semanas do seguimento, sem carga por 3 semanas e carga parcial nas 3 seguintes. A regressão do edema ósseo, da dor no repouso e da dor em atividades são analisadas. Uma correlação é encontrada entre a redução do edema com a redução da dor durante a atividade, porém não com a redução da dor em repouso.

Englund et al. ${ }^{13}$, em 2010, estudam a relação de lesões meniscais com o aumento ou surgimento de novos edemas ósseos. Um total de 1344 joelhos com osteoartrite ou em risco do estudo MOST são acompanhados. O risco relativo de surgimento de novas lesões de edema ósseo é de 1,5 em joelhos com alteração do menisco medial e de 4,3 nos com alteração do lateral. O risco correspondente para o aumento de edemas ósseos pré-existentes é de 2,4 para alterações meniscais do compartimento medial e 2,6 do lateral. Não é observada diferença quando comparado o risco relativo para lesão ou extrusão meniscal como variáveis de exposição separadas. 
Dore et al. ${ }^{12}$, em 2010, realizam estudo para avaliar a história natural da evolução de edema ósseo em seguimento médio de 2,7 anos. Em 25\% dos casos, as lesões observadas no início do estudo diminuem e em $24 \%$ aumentam. Em pacientes sem evidência radiográfica de osteoartrite, é encontrada uma associação entre alterações de dor e função com as variações do edema ósseo, não sendo encontrada essa mesma relação em pacientes com evidências radiográficas de osteoartrite. Uma correlação entre a gravidade do edema ósseo no início do estudo e a realização da artroplastia total do joelho (OR 2,1) é também demonstrada.

Roemer et al. ${ }^{25}$, em 2010, avaliam a associação entre a erosão do osso subcondral com o edema ósseo. A erosão do osso subcondral é definida como o achatamento ou depressão da superfície óssea articular. Em avaliação de 1025 joelhos do estudo MOST, é encontrada uma forte associação entre a presença do edema ósseo e a prevalência de erosão subcondral no mesmo compartimento e também com o surgimento de novas áreas de erosão durante o seguimento de 30 meses.

Tanamas et al. $^{28}$, em 2010, realizam estudo com o acompanhamento de 108 pacientes com osteoartrite, no qual encontram uma associação entre presença inicial de edema ósseo e um menor volume condral no planalto tibial assim como a redução do volume condral em dois anos de seguimento. É observada uma associação entre o aumento do edema ósseo e a redução do volume condral e aumento do risco de realização de artroplastia total do joelho acometido em 4 anos.

Zhao et al. ${ }^{30}$, em 2010, utilizam uma avaliação quantitativa T1rho em ressonância magnética para mensuração da progressão da degeneração condral em pacientes com osteoartrite. É demonstrada uma associação entre maiores valores de T1rho com a presença do edema ósseo no início do estudo. Também são observados maiores valores de T1rho na cartilagem sobre os edemas ósseos, quando comparada com a 
cartilagem do mesmo compartimento, sobre osso sem alterações de sinal. Durante o seguimento de um ano, é observado um aumento mais expressivo dos valores de T1rho nas áreas de edema ósseo. Um último dado apresentado nesse estudo é a associação entre o aumento da intensidade do edema ósseo, porém não do volume, com a maior elevação do valor de T1rho, sugerindo que a intensidade do sinal possa ser um dado mais relevante que o volume do edema para a avaliação da gravidade da lesão.

Segal et al. ${ }^{48}$, em 2012, demonstram que a elevação da média e pico de estresse de contato está associada à piora da morfologia da cartilagem e à progressão do edema ósseo em pacientes com osteoartrite, em um seguimento de 30 meses.

Kazakia et al. $^{49}$, em 2013, realizam estudo com a avaliação de 18 peças de planalto tibial retirados durante a artroplastia de joelho de 10 pacientes. Os autores encontram maiores frações de volume ósseo e maior espessura do trabeculado ósseo nas áreas de edema ósseo. Nessas áreas, identifica-se um trabeculado com menor taxa de fósforo e carbono, um infiltrado colágeno fibroso e aumento do remodelamento ósseo. Tais alterações coincidem com a topografia de degeneração da cartilagem articular. Os achados reforçam a correlação local entre o conjunto cartilagem, osso e medular, no desenvolvimento da osteoartrite.

Ratzlaff et al. ${ }^{50}$, em 2013, validam um novo sistema de mensuração automatizada do volume do edema ósseo. No mesmo estudo, realizam uma validação clínica do método, na qual encontram uma associação entre a dor no joelho ao suportar carga com o volume total do edema ósseo no fêmur. Não é observada a mesma associação com o volume do edema tibial.

Lim et al. ${ }^{21}$, em 2013, realizam uma revisão sistemática da literatura e encontram uma forte relação entre o alinhamento mecânico dos membros inferiores e lesões 
meniscais com a presença de edema ósseo em pacientes com osteoartrite. Os estudos incluídos apresentam importante heterogeneidade de sintomas e grau radiográfico da osteoartrite dos participantes.

Lim et al. ${ }^{20}$, em 2014, em revisão sistemática da literatura encontram uma forte associação entre a concentração sérica de colesterol e a presença de edema ósseo em pacientes com osteoartrite. Já em pacientes com obesidade, é evidenciada uma associação moderada. A revisão inclui 30 estudos, sendo 17 considerados de alta qualidade, porém com significativa heterogeneidade de sintomas e estágio radiográfico da osteoartrite entre as populações dos estudos.

Beckwée et al. ${ }^{51}$, em 2015, realizam uma a revisão sistemática com meta-análise para avaliar a influência da carga no joelho nas lesões da medular óssea. Aumentos de carga no compartimento (momento de adução e alinhamento do membro) e lesão estruturais do compartimento (lesões de menisco ou cartilagem) aumentam o risco de presença e progressão da lesão medular óssea. O peso corporal também aumenta o risco da presença da lesão, porém em menor grau. Já a atividade física apresenta resultados contraditórios.

Zhu et al. ${ }^{52}$, em 2016, estudam a associação do nível sérico da Proteína C Reativa (PCR) com a lesão óssea medular e a dor em paciente com osteoartrite do joelho. Durante um período de 24 meses, são avaliados 192 pacientes. Os autores relatam que um maior nível de PCR no início do seguimento está relacionado com a presença da lesão óssea medular. Durante o seguimento, uma alteração do nível de PCR está positivamente associada às escalas de mensuração da lesão. Os níveis de PCR têm fraca associação com o grau de dor dos pacientes, não sendo significante após ajustes pelas alterações das lesões ósseas medulares. 
Teichtahl et al. $^{53}$, em 2017, realizam análise de pacientes da coorte Osteoarthritis Initiative e observam a associação entre a presença do edema ósseo no platô tibial com perda acelerada do volume de cartilagem, progressão radiográfica da osteoartrite e maior risco de ser submetido à artroplastia do joelho. A análise de progressão dos parâmetros avaliados é realizada após 48 meses da avaliação inicial. Nos pacientes sem critérios de osteoartrite na radiografia da avaliação inicial, a presença de lesão óssea medular é um fator de risco para o desenvolvimento de osteoartrite durante o período de seguimento. No mesmo estudo também é observada associação semelhante entre a extrusão do menisco com a progressão da osteoartrite de joelho, através dos mesmos parâmetros.

Hussain et al. ${ }^{54}$, em 2017, em uma revisão sistemática da literatura com inclusão de 26 artigos, identificam a alta prevalência de menisectomias e lesões meniscais em pacientes com osteonecrose primária do joelho. São identificadas principalmente lesões da raiz posterior do menisco medial, que aumentam de forma significativa a pressão de contato no compartimento, criando um ambiente favorável à fraturas de insuficiência. Os autores sugerem ainda que o termo osteonecrose é uma interpretação equivocada da etiologia e patogênese da doença, devendo-se considerar sua substituição pelo termo fratura de insuficiência..

Muratovic et al. ${ }^{55}$, em 2018, analisam 84 peças de platôs tibiais ressecados durante artroplastias do joelho e comparam os achados histológicos entre as áreas com e sem edema medular ósseo. Nas áreas de edema medular ósseo, são encontrados uma maior quantidade de microfraturas, maior densidade de osteócitos, maior densidade arteriolar e alteração das características vasculares (paredes arteriais espessadas e aumento do índice parede/lúmen). Os autores acreditam que tais achados corroboram com a teoria mecânica na gênese da lesão óssea medular, pela presença 
das microfraturas, assim como as alterações arteriais locais demonstram um fator vascular nessas lesões.

\subsection{Nomenclatura e classificação do edema ósseo}

Hofmann et al. ${ }^{8}$, em 2004, em artigo de revisão classificam os edemas ósseos identificados em ressonância magnética em três grandes grupos: isquêmico, mecânico e reativo. O grupo de edemas isquêmicos inclui osteonecrose (primária e secundária), síndrome do edema medular ósseo, osteocondrite dissecante e distrofia simpática reflexa. O grupo de edemas mecânicos inclui contusão, microfraturas, sobrecarga e fratura de estresse. Já o último grupo, de edemas reativos, inclui as artrites infecciosas, a osteoartrite, o edema pós-operatório e os neoplásicos.

Roemer et al. ${ }^{9}$, em 2009, publicam artigo baseado em uma revisão da literatura e consenso de especialistas com uma divisão dos edemas ósseos. Os autores dividem os edemas ósseos em dois grupos maiores de edemas traumáticos e não traumáticos. $\mathrm{O}$ primeiro grupo de edemas traumáticos inclui contusão óssea, fraturas, osteonecrose primária do joelho, fratura de insuficiência e por sobrecarga. O segundo grupo de edemas não traumáticos inclui os de origem vascular (osteonecrose secundária), os associados à osteoartrite, as síndromes de edema transitório, a osteocondrite dissecante, os tumores e os edemas reacionais.

Folkes et al. ${ }^{7}$, em 2010, revisam as causas do edema ósseo em ressonância magnética separando as mesmas em 6 diferentes classes: osteoartrite, trauma, necrose, síndromes de edema ósseo transitório, tumores e inflamatória. Nessa divisão, o grupo 'trauma' inclui as contusões e trações decorrentes de trauma agudo e o grupo 'necrose' inclui tanto a osteonecrose primária quanto a secundária. O grupo de 
síndromes de edema ósseo transitório inclui a osteoporose transitória e a osteoporose regional migratória, sobre a qual os autores questionam se não fariam parte do processo de uma possível osteonecrose primária.

Manara et al. ${ }^{3}$, em 2014, publicam artigo de revisão no qual dividem os edemas ósseos em 8 classes: trauma, degenerativo, inflamatório, vascular, infeccioso, metabólico, iatrogênico e neoplásico. Dentro do subgrupo do trauma, estão incluídos os seguintes itens: fraturas, osteoporose transitória, sobrecarga, contusão e lesões osteocondrais. A classe degenerativa inclui a osteoartrite e a classe inflamatória as artrites inflamatórias e inflamações sistêmicas. A classe vascular inclui a osteonecrose secundária e a distrofia simpática reflexa; e a classe metabólica inclui a gota e as doenças de depósito de hidroxiapatita. A classe iatrogênica inclui os edemas póscirúrgicos.

Collins et al. ${ }^{6}$, em 2016, em artigo de revisão sobre o edema ósseo medular, destacam a imprecisão da literatura na nomenclatura sobre o assunto, com a alteração observada em ressonância magnética podendo ser causada por um amplo espectro de diagnósticos. Os autores dividem as lesões em três grupos: isquêmico, mecânico e reativo. No primeiro grupo estão incluídos a osteonecrose secundária, a osteonecrose primária, a osteocondrite dissecante e a distrofia simpática reflexa. O grupo de origem mecânica inclui o mau alinhamento de membro, as lesões ligamentares e meniscais, as contusões, a sobrecarga e as fraturas. Já o último grupo, reativo, inclui infecções e tumores.

Kon et al. $^{2}$, em 2016, em artigo de revisão, classificam o edema ósseo de duas formas distintas, sendo a primeira em lesões traumáticas e não traumáticas e, a segunda classificação, em lesões reversíveis e não reversíveis. Nas lesões traumáticas, os autores incluem a lesão traumática subcondral contusional ou por avulsão. Já entre 
as não traumáticas, os autores incluem diversos diagnósticos com algumas subdivisões. Uma primeira subdivisão inclui as lesões degenerativas, presentes na osteoartrite, geralmente associadas às lesões da cartilagem e menisco. Um segundo subgrupo inclui patologias reversíveis (osteoporose transitória, osteoporose regional migratória, distrofia simpática reflexa) e não reversíveis (osteonecrose primária e secundária), tendo ainda a fratura de insuficiência como uma condição que pode se encaixar nas duas situações. O último subgrupo inclui os edemas ósseos que surgem após as cirurgias para o tratamento de lesões condrais. $\mathrm{O}$ artigo ainda pontua outras causas de alteração na imagem da ressonância magnética, como a erosão óssea por doenças inflamatórias, alterações da hematopoese, neoplasias e desuso.

\subsection{Subcondroplastia}

Sharkey et al. ${ }^{56}$, em 2012, apresentam o primeiro relato de caso com uso da subcondroplastia para o tratamento de uma lesão de edema ósseo em um paciente com osteoartrite. Uma paciente do sexo feminino, com 51 anos de idade, apresenta-se com dor no joelho há 8 meses, sem melhora de sintomas com tratamento conservador, sendo evidenciada uma lesão de edema ósseo no planalto tibial medial no exame de ressonância magnética. A paciente foi submetida à artroscopia que evidenciou avançada degeneração condral do planalto tibial medial. A mesma é submetida à subcondroplastia no local da lesão, apresentando importante melhora de dor e de qualidade de vida, com manutenção dos resultados obtidos até o seguimento final, 31 meses após o procedimento. 
Nesse primeiro artigo, os autores apresentam o racional para o desenvolvimento da técnica, com uma reestruturação da integridade estrutural do osso subcondral associado a um estímulo a reparação do osso afetado.

Em 2013, Abrams et al. ${ }^{57}$ expandem a indicação do uso da subcondroplastia para o tratamento de lesões de osteocondrite dissecante, com a apresentação de um caso de osteocondrite dissecante no planalto tibial lateral, tratado com a técnica. Os autores indicam a injeção do fosfato de cálcio no osso subcondral, abaixo da lesão da osteocondrite, em pacientes com lesões estáveis, com dor no local, associada à presença de edema ósseo na imagem de ressonância magnética. A indicação tem o objetivo de estabilizar mecanicamente a lesão, reduzindo a dor do paciente até a reparação do osso subcondral.

Farr et al. $^{58}$, em 2013, também acrescentam indicações para o uso da subcondroplastia com a descrição do uso da técnica também na articulação femoropatelar. No mesmo artigo, os autores apresentam uma coorte retrospectiva de 59 casos com um seguimento médio de 14,7 meses, com $83,1 \%$ dos pacientes com mais de 6 meses de seguimento. Os pacientes com mais de 6 meses de seguimento apresentam uma melhora da escala visual analógica (EVA) de dor de 7,5 para 3,1, da escala da International Knee Documentation Commitee (IKDC) de 30,6 para 53 e da escala de qualidade de vida SF-12 de 39,8 para 36,7 no seguimento final. Quinze pacientes $(25 \%)$ mantêm uma dor significativa no joelho, optando pela realização da artroplastia de joelho em um período médio de 10,1 meses após a subcondroplastia.

Caetterjee et al. ${ }^{59}$, em 2015, realizam estudo retrospectivo com a avaliação de 22 pacientes submetidos à subcondroplastia com um seguimento mínimo de 6 meses. A média da Injury and Osteoarthritis Outcomes Score (KOOS) pré-operatória foi de $39,5( \pm 21,8)$ e no pós-operatório de $71,3( \pm 23)(\mathrm{p}<0,01)$. Já pela escala de Tegner 
Lysholm, a média pré-operatória foi de $48( \pm 15,1)$ e pós-operatória de $77,5( \pm 20,6)$ $(p<0,01)$. Uma correlação inversa entre o grau de osteoartrite pela escala de KellgrenLawrence e a escala de Tegner Lysholm pós-operatória é identificada, demostrando que quanto mais avançada a degeneração articular, pior torna-se o resultado funcional final. Os autores consideram pela escala de Tegner Lysholm que 7 dos 22 pacientes obtêm um resultado ruim, 3, moderado, 5, bom e 7, excelente. Dessa forma, os autores concluem que a subcondroplastia é uma técnica ineficiente para o tratamento das lesões de edema ósseo na osteoartrite, por uma taxa de sucesso de apenas 55\%.

Wyland $^{60}$, em carta ao editor, questiona a conclusão dos autores, justificando que a graduação da escala de Tegner Lysholm é definida para pacientes submetidos à reconstrução do ligamento cruzado anterior e não para pacientes com osteoartrite. Também argumenta que dos 22 pacientes operados, 20 (91\%) obtêm alguma melhora quando comparados à função pré-operatória.

Colon et al. ${ }^{61}$, em 2015, realizam estudo comparando o comportamento de penetração no osso de sete marcas diferentes de substitutos ósseos disponíveis no mercado nos Estados Unidos, para o procedimento de subcondroplastia. Testes biomecânicos são realizados, simulando a injeção do material em blocos de polietileno que reproduzem a estrutura do trabeculado ósseo metafisário. Dos sete produtos testados, dois $\left(\right.$ AcuFill $^{\circledR}$ e StructSure $\left.{ }^{\circledR}\right)$ possibilitam a injeção. O restante dos materiais entra em fase de separação devido a pressões maiores de injeção e não atravessam o orifício de saída da seringa.

Em 2015, Cohen et al. ${ }^{62}$ publicam uma coorte retrospectiva de 66 pacientes submetidos à subcondroplastia. São incluídos pacientes que procuram os autores com indicação de artroplastia do joelho, que apresentam lesão de edema medular ósseo na ressonância magnética e dor localizada na topografia da lesão. Pacientes dessa coorte 
apresentam sintomas em média há 22,4 meses, com falha de tratamento conservador, com uma osteoartrite até grau 3 pela escala radiográfica de Kellgreen-Lawrence. É observada uma melhora significativa da EVA de dor, com uma melhora média de 4,3 em 6 meses e 4,5 pontos em dois anos de seguimento. A escala de IKDC subjetivo também apresenta uma melhora de 17,2 e 17,8 pontos em seis meses e dois anos de seguimento, respectivamente. A análise de Kaplan-Meier demonstra uma sobrevida de preservação da articulação (não realização da artroplastia) de 70\% em dois anos.

Agten et al. ${ }^{63}$, em 2016, descrevem os achados de imagem em radiografia, tomografia e ressonância magnética de 9 pacientes submetidos à subcondroplastia. Os autores descrevem a ocorrência de extravasamento do substituto ósseo em partes moles, que é reabsorvido com o tempo e não deve ser confundido com ossificações. Na ressonância, são descritas áreas de baixa intensidade nos locais de injeção, sendo que, nos primeiros 6 meses, a área ocupada pelo material injetado pode apresentar uma borda de alto sinal nas ponderações sensíveis a líquido. Já na tomografia, observa-se o fácil reconhecimento do trajeto da cânula de injeção assim como a presença do extravasamento para partes moles.

Yoo et al. ${ }^{64}$, em 2016, avaliam 22 pacientes submetidos a 23 artroplastias do joelho, sendo 7 unicompartimentais e 16 totais, após a realização da subcondroplastia. Os autores avaliam os resultados clínicos iniciais, complicações e dificuldades técnicas. Quando comparados a um grupo controle pareado de pacientes sem a realização prévia da subcondroplastia, não são encontradas diferenças significativas quanto aos três quesitos.

Bonadio et al. ${ }^{65}$, em 2017, realizam estudo com uma série de casos iniciais com 5 pacientes submetidos à subcondroplastia, avaliando os resultados clínicos durante um seguimento de 6 meses. O estudo utiliza um substituto ósseo (Graftys 
HBS () diferente dos estudos anteriores de subcondroplastia. Os autores conseguem injetar o substituto ósseo nas áreas de edema ósseo medular e obtêm melhora significativa na escala de KOOS e na dor dos pacientes. Como complicações, é descrito um procedimento com extravasamento do substituto ósseo para partes moles, sem necessidade de procedimentos adicionais e sem comprometimento do resultado.

Dold, Parretta e Youm ${ }^{66}$, em 2017, reportam um caso de osteomielite após injeção de substituto ósseo à base de fosfato de cálcio. O paciente apresenta uma saída de secreção após a primeira semana do procedimento, que é tratada com sete dias de cefalexina. Após 4 meses da subcondroplastia, apresenta novamente saída de secreção, sendo diagnosticada uma coleção intraóssea. É realizado um desbridamento cirúrgico, havendo aspecto purulento do conteúdo da coleção intraóssea. Na cultura da ferida operatória, um Staphylococcus aureus multissensível é isolado, sendo realizado tratamento com antibiótico endovenoso por 6 semanas, com resolução completa da infecção em até um ano de seguimento.

Astur et al. ${ }^{67}$, em 2018, realizam uma revisão da literatura para avaliação da técnica de injeção de fosfato de cálcio no osso subcondral, para o tratamento das lesões da medular óssea. Os autores levantam 8 estudos com um total de 164 pacientes. Os estudos avaliados demonstram melhora funcional dos pacientes. Como resultado do levantamento, os autores concluem que ainda existem poucos trabalhos avaliando a técnica e, apesar dos bons resultados obtidos até o momento do levantamento, ainda são necessários estudos com maior nível de evidência para melhor compreensão da indicação e técnica do procedimento.

Bernhard et al. ${ }^{68}$, em 2018, reportam um caso de uso da subcondroplastia para o tratamento de uma fascite plantar que falhou ao tratamento inicial com fasciectomia. A subcondroplastia é realizada no osso calcâneo próximo à origem da fáscia plantar, 
onde existia um edema ósseo medular, associada à nova fasciectomia. O paciente obtém uma melhora progressiva dos sintomas conseguindo voltar às atividades esportivas completas após 3 meses do procedimento. Os autores concluem que a subcondroplastia pode ser considerada quando existir a possibilidade de a dor ter origem no edema ósseo medular, porém essa é apenas uma descrição isolada de um caso.

Brimmo et al. ${ }^{69}$, em 2018, realizam estudo para avaliar o uso da subcondroplastia no tratamento da lesão medular óssea pós-traumática em modelo canino. Este é um estudo duplo cego randomizado, com 32 joelhos, sendo um grupo tratado com subcondroplastia e um grupo controle, com a introdução da mesma cânula, porém sem injeção do substituto ósseo. Os animais são avaliados com 3, 6, 12 e 24 meses, referente à função clínica dos joelhos, dor, derrame articular e perda do arco de movimento. O grupo da subcondroplastia apresenta diferença significativa apenas nas avaliações de 12 e 24 meses, com uma menor perda do arco de movimento. A avaliação da MicroTC identifica uma maior fração de volume ósseo e maior espessura trabecular um ano após a cirurgia, o que não se repete na análise de dois anos.

\section{MÉTODOS}

O presente estudo foi realizado no Instituto de Ortopedia e Traumatologia do Hospital das Clínicas da Faculdade de Medicina da Universidade de São Paulo (IOTHCFMUSP). Foi obtida aprovação pela Comissão Científica do IOTHCFMUSP e pela Comissão de Ética para análise de projetos de pesquisa do Hospital das Clínicas da Faculdade de Medicina da Universidade de São Paulo (CAPPESQ) 
(Anexo 1). Foi obtido também consentimento informado dos pacientes incluídos (Anexo 2). O presente estudo está registrado no ClinicalTrial.gov com identificação NCT03941977.

\subsection{Critérios de Inclusão}

Para o presente estudo, foram incluídos pacientes do ambulatório do Grupo de Joelho do Instituto de Ortopedia e Traumatologia do HCFMUSP, segundo os seguintes critérios de inclusão:

- $\quad$ Idade entre 40 e 85 anos;

- Ambos os gêneros;

- Dor no joelho há pelo menos 6 meses;

- Imagem de alto sinal em região subcondral de planalto tibial ou côndilos femorais na ponderação em T2 com supressão de gordura da ressonância magnética.

\subsection{Critérios de Exclusão}

Foram estabelecidos como critérios de exclusão para o presente trabalho:

- Doenças hematológicas ativas;

- Insuficiência renal dialítica;

- Não deambular;

- Osteoartrite de joelhos com classificação radiológica de Kellgren-Lawrence superior a 3 ; 
- Alinhamento de membros inferiores em valgo ou varo superior a 8 graus em relação ao eixo mecânico;

- Alterações radiográficas degenerativas da articulação femoropatelar, associadas a sintomas de dor anterior do joelho.

\subsection{Avaliação inicial}

Todos os pacientes incluídos no estudo foram submetidos à avaliação inicial, na qual foram realizados os seguintes exames e escalas:

- Ressonância magnética do joelho acometido, conforme protocolo padrão da radiologia do IOTHCFMUSP;

- Radiografia panorâmica de membros inferiores para mensuração do alinhamento do membro;

- Radiografia em incidências anteroposterior com carga e perfil dos joelhos;

- Escalas funcionais de IKDC subjetivo, KOOS e SF-36v1;

- Escala visual analógica de dor.

\subsection{Exame de ressonância magnética}

Exames de ressonância magnética foram realizados em aparelho de 1,5 T (Signa Excite HD; GE Healthcare, Waukesha, WI, USA) e foi utilizada uma bobina específica para exames em joelho (HD TRKnee 8 Ch High Resolution Knee Array).

As sequências realizadas foram as estabelecidas para o atendimento da rotina assistencial de pacientes da nossa instituição. 
Detalhes sobre a sequência encontram-se no Anexo 3.

\subsection{Avaliação radiográfica e ressonância magnética}

As radiografias foram avaliadas e classificadas por um radiologista especialista em musculoesquelético, segundo a classificação de Kellgren-Lawrence. As radiografias não foram identificadas quanto ao momento de realização, antes ou após o procedimento. Porém, em muitos casos era possível se identificar sinais do procedimento na imagem, impossibilitando o cegamento do avaliador.

Nas imagens da ressonância magnética foi avaliada a localização do edema ósseo em relação ao osso acometido (fêmur ou tíbia) e o compartimento acometido (medial ou lateral). Também foi avaliada a extensão do edema dividida em três níveis conforme a porcentagem de acometimento da área do corte coronal do côndilo femoral ou platô tibial, sendo grau 1 menor que $25 \%$, grau 2 entre $25 \%$ e $50 \%$ e grau 3 maior que $75 \%$. No osso subcondral também foi registrada a presença de linha de fratura, cistos e impacções/colapsos da superfície articular. A presença de impacção foi aferida em milímetros (Figura 1). 


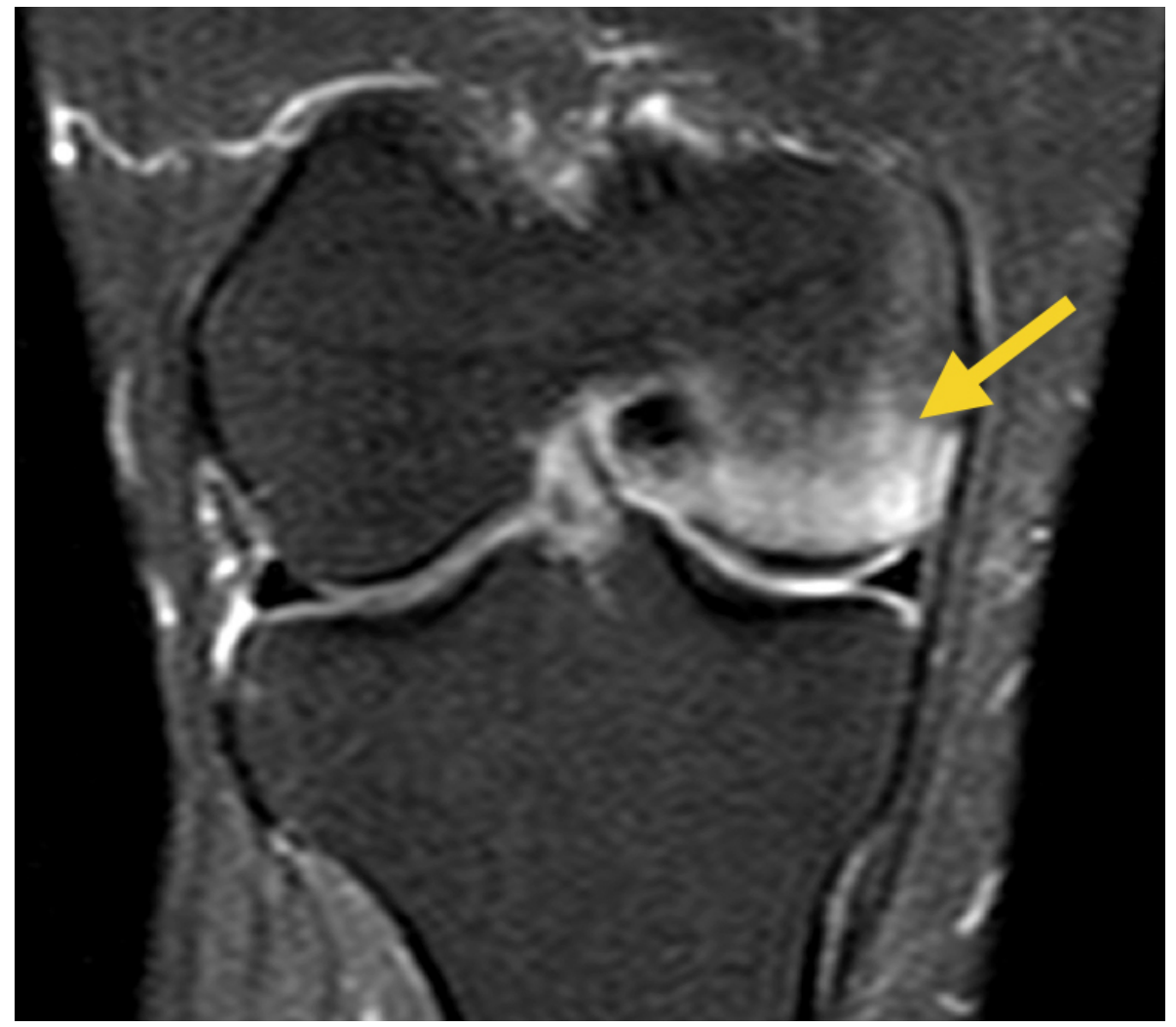

Figura 1 - Corte coronal de exame de ressonância magnética de joelho direito em ponderação T2, ilustrando um edema medial ósseo no côndilo femoral medial, correspondente à área de coloração branca apontada pela seta

\subsection{Avaliação clínica e funcional}

Os pacientes foram avaliados pelas escalas funcionais: KOOS (Anexo 4) e IKDC subjetivo (Anexo 5). Também foi avaliada a qualidade de vida pelo questionário SF36v1 (Anexo 6).

\subsection{Acompanhamento dos pacientes}

Os pacientes foram seguidos em consultas ambulatoriais com 1, 3, 6, 12, 24 e 48 semanas após o procedimento cirúrgico. As escalas funcionais foram repetidas em todas as consultas. A escala de qualidade de vida foi repetida com 24 e 48 semanas. As radiografias e ressonância magnética foram repetidas entre 48 e 52 semanas após a cirurgia sendo este um período possível para a programação do exame e dentro de um intervalo que não altere os resultados encontrados. 


\subsection{Descrição da técnica cirúrgica}

As ressonâncias magnéticas dos pacientes foram mapeadas no centro cirúrgico para definição da área da lesão, assim como o planejamento do ponto de injeção no centro da lesão, da trajetória e do ponto de entrada da cânula (Figura 2). A trajetória da cânula foi definida priorizando um ângulo adequado de ataque para o ponto de entrada e distâncias maiores de trajetória intraóssea, com o objetivo de evitar o extravasamento do substituto ósseo pelo orifício de entrada da cânula.
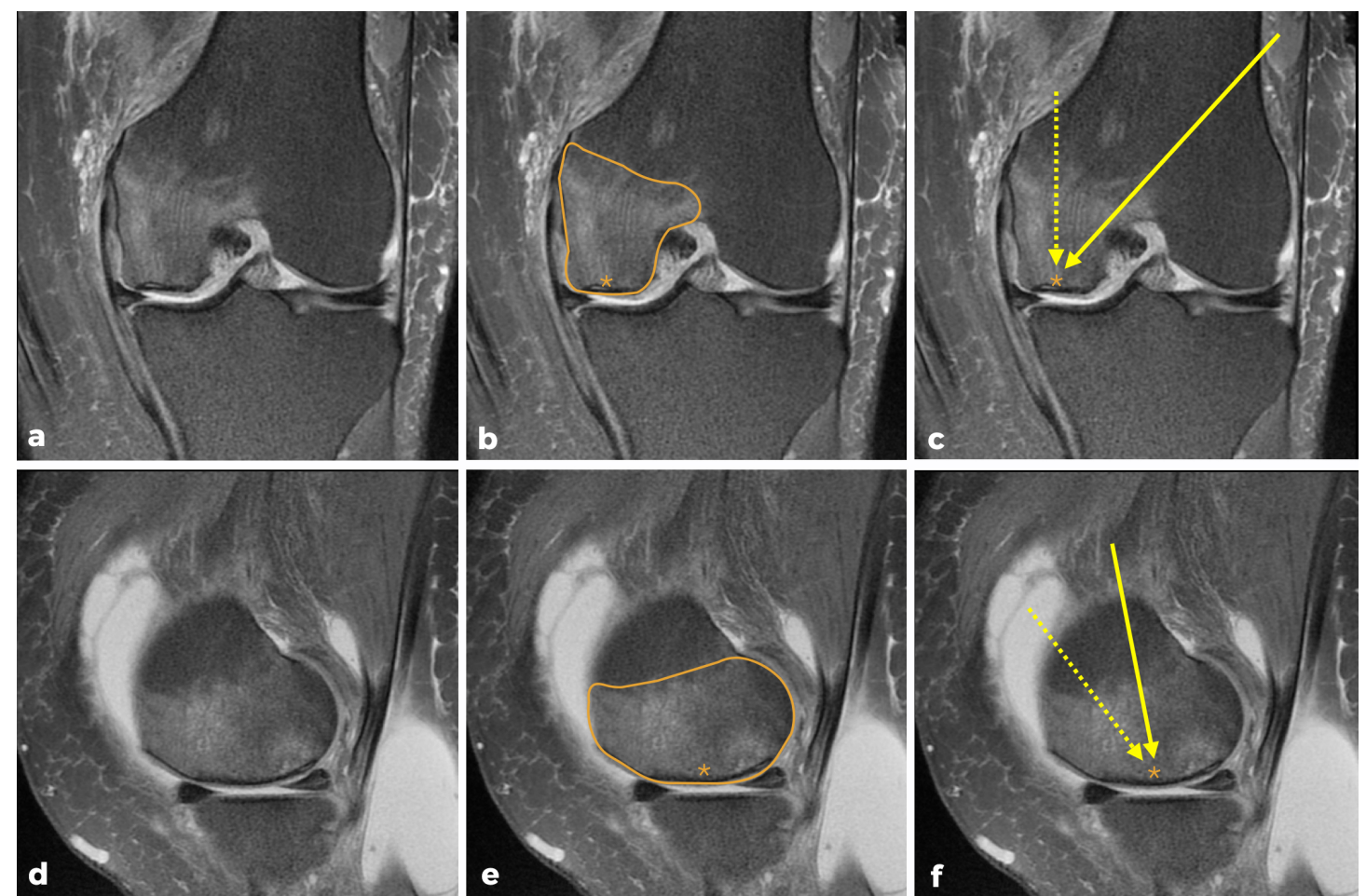

Figura 2 - Planejamento pré-operatório na imagem da ressonância magnética a) Corte coronal de ressonância magnética de joelho esquerdo em ponderação T2 com edema medular ósseo no côndilo femoral medial; b) Corte coronal com mapeamento da área do edema (linha laranja) e ponto alvo para injeção (asterisco em laranja); c) Corte coronal com duas opções de planejamento de trajetória para introdução da cânula (setas amarelas); d) Corte sagital de ressonância magnética de joelho esquerdo em ponderação T2 com edema medular ósseo no côndilo femoral medial; e) Corte sagital com mapeamento da área do edema (linha laranja) e ponto alvo para injeção (asterisco em laranja); f) Corte coronal com duas opções de planejamento de trajetória de introdução da cânula (setas amarelas) 
Os procedimentos foram realizados sob raquianestesia, em centro cirúrgico. Os pacientes foram posicionados em decúbito dorsal em mesa radiotransparente, com um coxim abaixo do quadril ipsilateral, para melhor controle da rotação externa do membro e um coxim também sob o joelho ipsilateral, auxiliando na incidência lateral da fluoroscopia, evitando a sobreposição da imagem do joelho contralateral.

O material para o procedimento foi:

- Uma cânula metálica de 8G com orifício de saída distal e lateral na ponta,

- Embolo metálico da cânula com ponta introdutória com corte,

- Embolo metálico da cânula com ponta romba,

- Torneira descartável de três vias de alto fluxo para infusão,

- Cinco seringas de $1 \mathrm{~mL}$ com rosca na ponta,

- Uma seringa de preparo do substituto ósseo Graftys HBS®.

Conforme planejamento pré-operatório, com auxílio da fluoroscopia em incidências de frente e perfil, o ponto de entrada da cânula foi demarcado, com o posicionamento da cânula sobre a pele (Figuras 3, 4 e 5). Incisões de $5 \mathrm{~mm}$ de comprimento foram realizadas com lâmina de bisturi n.11 no ponto de entrada na pele. As cânulas foram introduzidas, com controle da fluoroscopia, em direção ao centro da lesão previamente determinado (Figura $2 \mathrm{~b}$ e $2 \mathrm{e}$ ). A progressão foi feita manualmente ou com auxílio de martelo, quando encontrada maior resistência. 

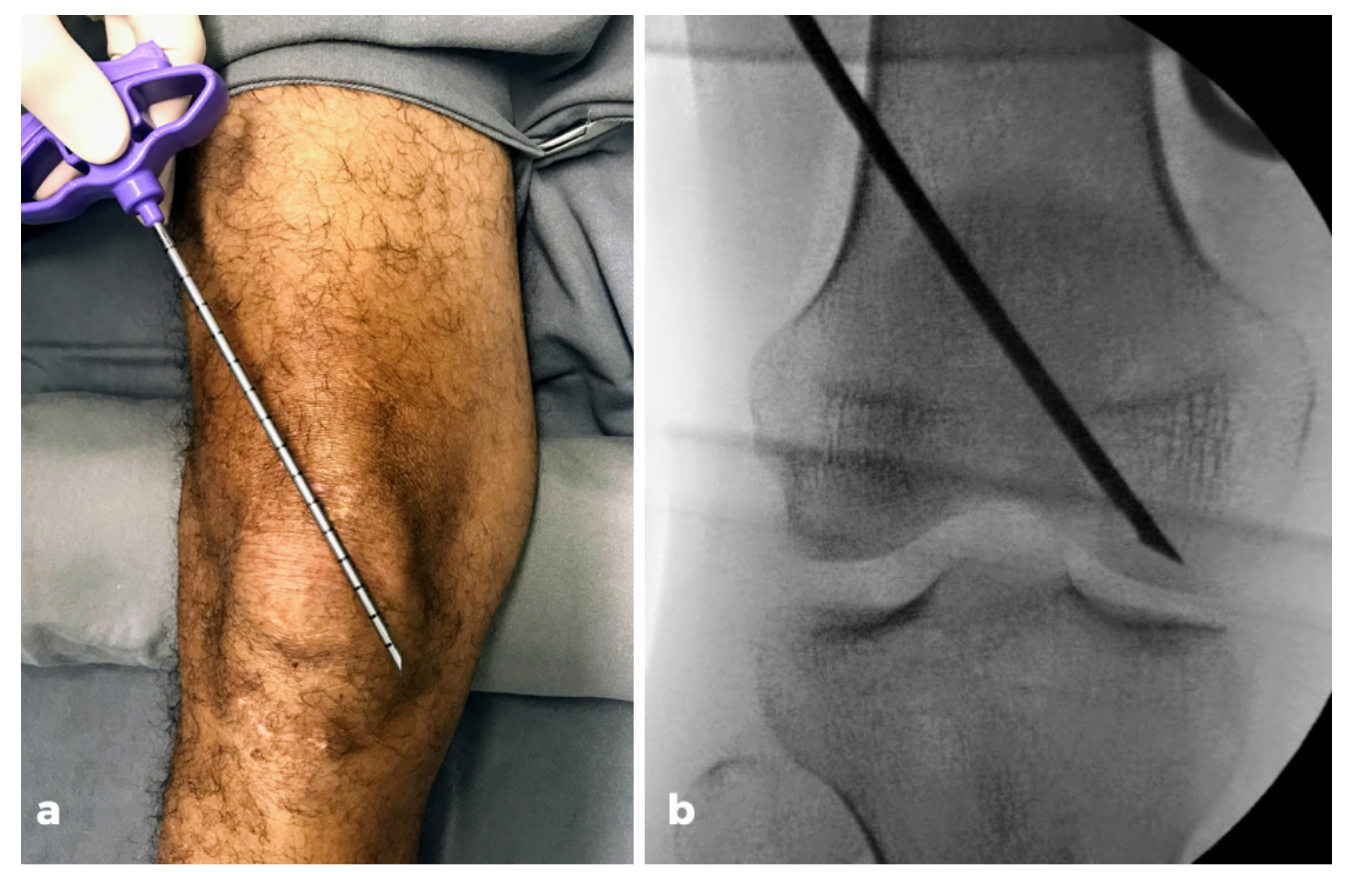

Figura 3 - a) Fotografia com visão anterior de joelho direito com cânula sobre o joelho para programação de trajeto para introdução da cânula; b) Imagem de fluoroscopia intraoperatória em incidência anteroposterior do planejamento do trajeto da cânula de superolateral para inferomedial, com alvo no côndilo femoral medial
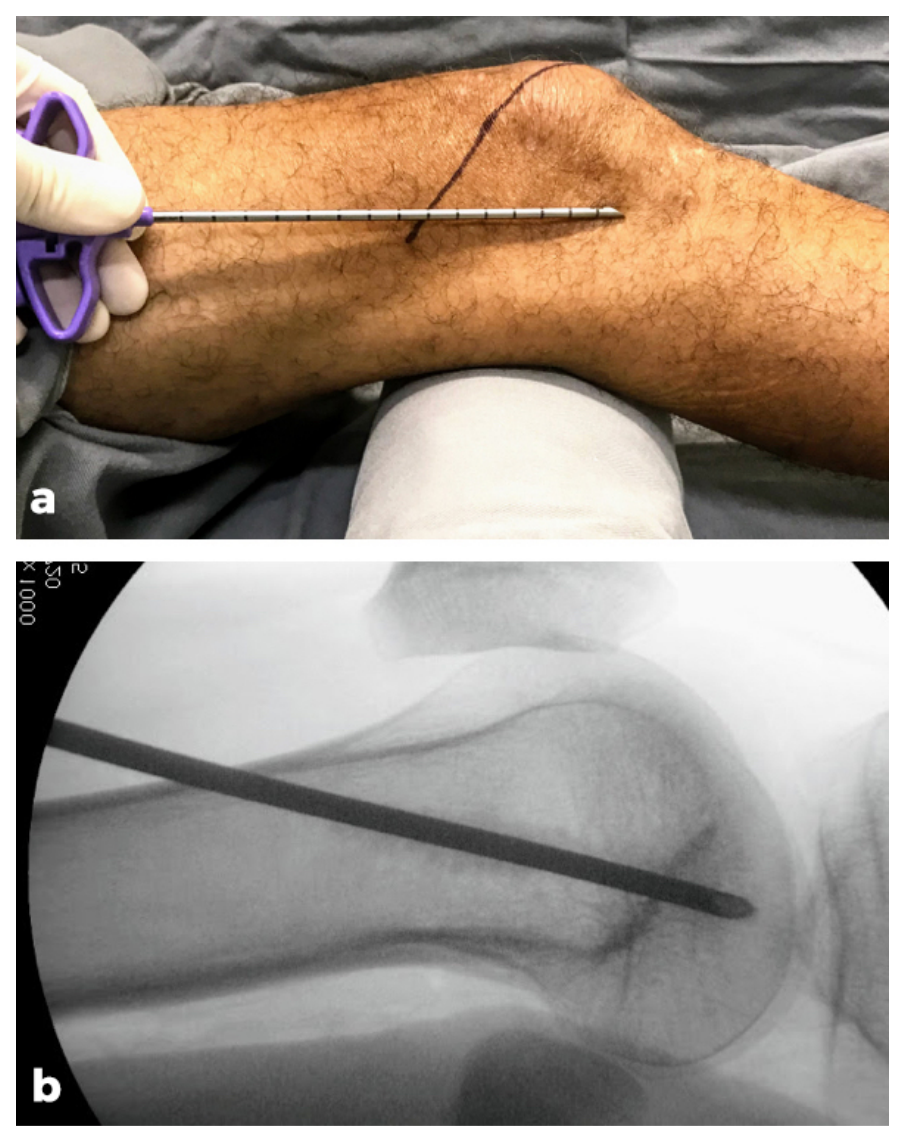

Figura 4 - a) Fotografia com visão lateral do joelho direito com cânula sobreposta para programação do trajeto para introdução da cânula; b) Imagem de fluoroscopia em incidência de perfil do planejamento do trajeto para introdução da cânula 


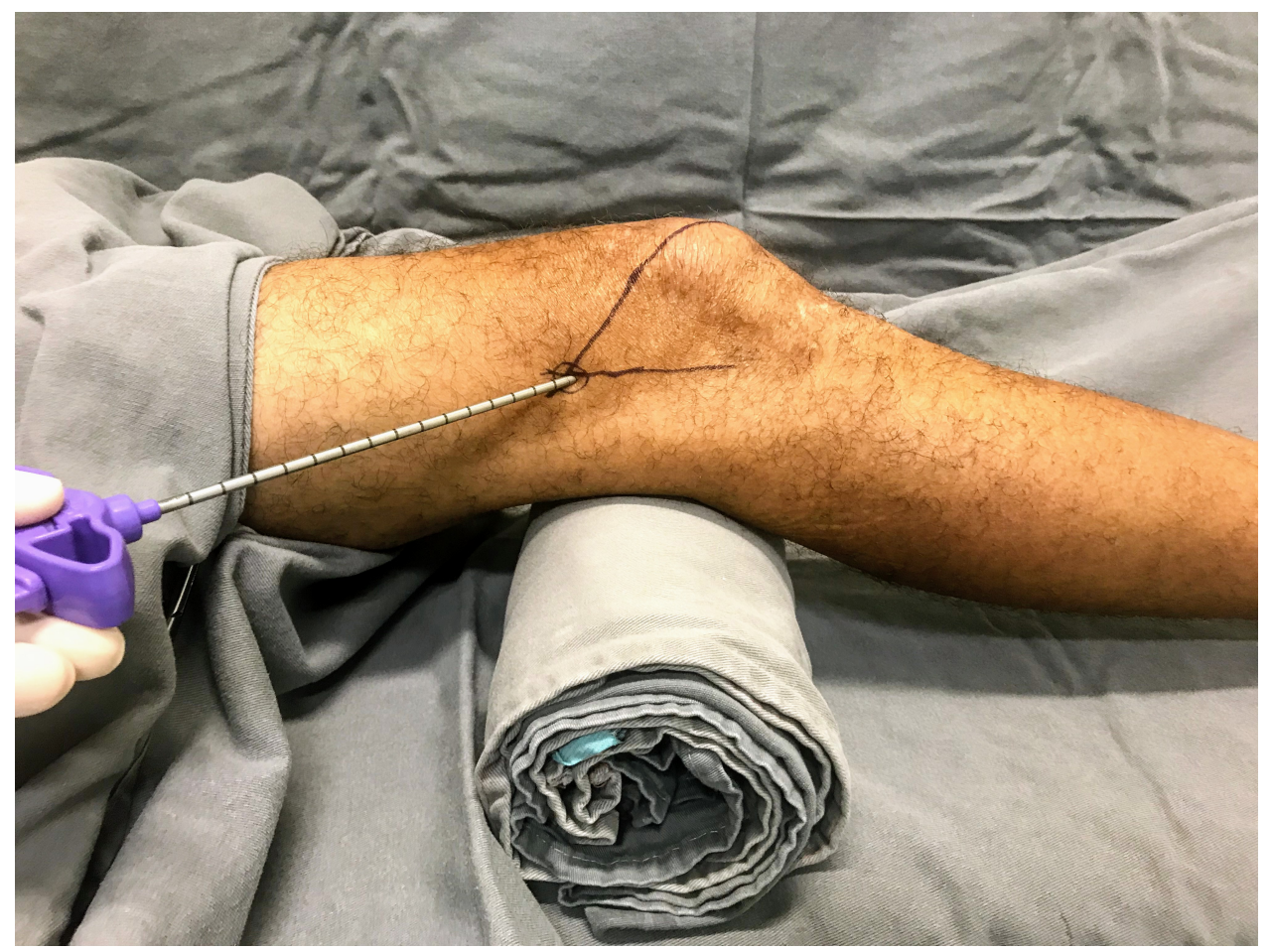

Figura 5 - Fotografia em visão lateral de joelho direito com linha desenhada no trajeto planejado para introdução de cânula posicionada no seu ponto de entrada, conforme direção do planejamento

Durante a introdução da cânula, incidências oblíquas de fluoroscopia foram realizadas para evitar a perfuração da cortical oposta, sendo a introdução da cânula realizada de forma bastante cuidadosa ao se aproximar da cortical oposta, com a possibilidade de utilização da ponta romba para cânula, dificultando a perfuração da cortical.

O substituto ósseo foi então preparado com a mistura do conteúdo sólido com o líquido até alcançar estado líquido/pastoso e transferido para seringas de $1 \mathrm{ml}$. A transferência para seringas de menor diâmetro é importante para conseguir um fluxo de injeção com aplicação de menor pressão. Os substitutos ósseos quando submetidos a pressões maiores passam para uma fase de separação na qual o líquido se separa da parte sólida, impossibilitando a entrega do material na área desejada. 
As seringas de $1 \mathrm{ml}$ foram conectadas nas cânulas já posicionadas no local determinado para o preenchimento. O substituto ósseo foi injetado, intercalando a passagem de um êmbolo metálico pela cânula, entre cada seringa. Por meio de fluoroscopia foi possível visualizar a distribuição do produto na medular óssea, garantindo que a aplicação estava de acordo com o mapeamento da lesão e controlando a presença de possíveis extravasamentos. A quantidade de produto injetada era definida pelo controle de preenchimento da área da lesão pela fluoroscopia. Em casos de extravasamento intra-articular, a injeção era interrompida. Após finalizada a injeção, aguardou-se 5 minutos antes da retirada da cânula, com intuito de reduzir o refluxo do material pelo orifício de entrada (Figura 6).

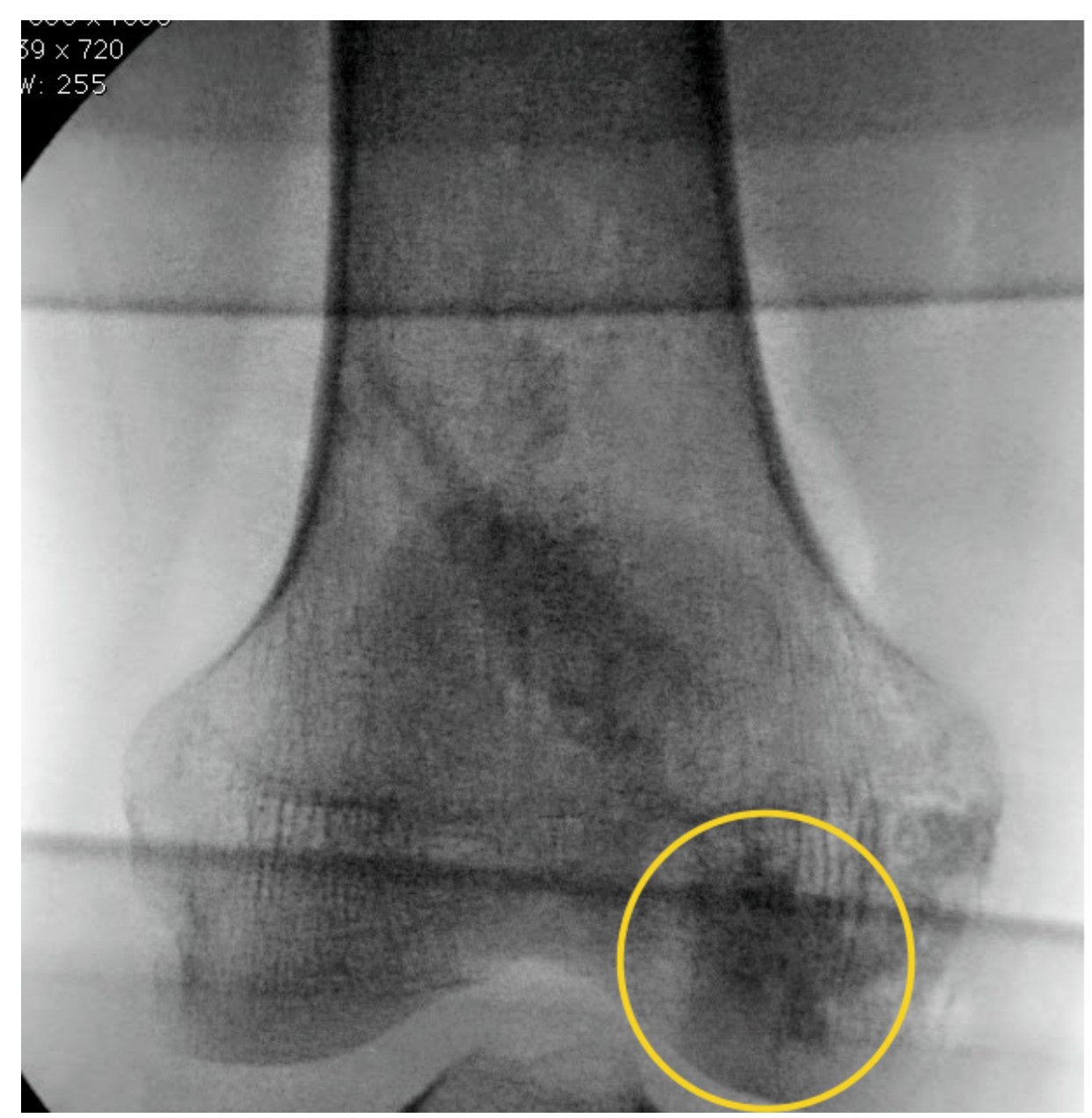

Figura 6 - Imagem de fluroscopia intraoperatória em incidência anteroposterior de joelho direito, após retirada da cânula, com possível visualização do substituto ósseo injetado na área de mais radiopaca no côndilo femoral medial circulada em amarelo 


\subsection{Substituto ósseo}

Para escolha do substituto ósseo mais adequado para o procedimento de subcondroplastia, foi procurado um substituto ósseo que possuísse características que possibilitassem a boa realização da técnica cirúrgica e o sucesso dos resultados. O produto deve ter uma adequada injetabilidade, permitindo a saída da seringa pela cânula e permear entre as trabéculas ósseas sem danificar as mesmas. Também deve ter um processo de solidificação/cristalização que não emita calor, para evitar a danificação da área injetada, com um tempo de trabalho (do preparo até a solidificação) suficiente para o procedimento. Uma vez completo o processo de solidificação, o material deve ter uma consistência semelhante a do osso metafisário local, possibilitando o auxílio no suporte e distribuição de carga, porém sem causar uma área de maior rigidez. Por último, deve ser um produto osteocondutor, permitindo o crescimento ósseo para regeneração da área tratada.

O Graftys $\mathrm{HBS} \circledast$ é um composto de fosfato de cálcio, formado através da mistura de uma parte sólida (sais de fosfato de cálcio) com uma parte líquida (solução aquosa de fosfato de sódio), com um tempo de trabalho de 15 minutos, podendo ser injetado por uma cânula de $14 \mathrm{G}$ ou de maior. Possui uma reação de cristalização com aumento de temperatura máximo de três graus Celsius, com uma porosidade final com adequada osteocondução para integração e substituição óssea. Ao final do processo de cristalização, o Graftys HBS ${ }^{\circledR}$ apresenta uma resistência de compressão de $14 \mathrm{Mpa}^{70}$. Devido a essas características o Graftys $\operatorname{HBS}{ }^{\circledR}$ foi considerado adequado para a técnica de subcondroplastia.

\subsection{Cuidados pós-operatórios}


Determinamos como período de internação dos pacientes uma noite. Desta forma, os pacientes receberam alta hospitalar no dia seguinte do procedimento. Foi permitida carga total conforme dor, com amplitude de movimento livre. Durante a internação os pacientes receberam analgesia com dipirona $1 \mathrm{~g}$ por via endovenosa realizada de $6 \mathrm{em}$ 6 horas, associada a tramadol 100mg endovenoso de 8 em 8 horas, se apresentassem dor forte maior que 7. Após a alta, os pacientes receberam analgesia com dipirona $1 \mathrm{~g}$ via oral de 6 em 6 horas, associada a tramadol 100mg via oral de 8 em 8 horas, se dor forte, por uma semana.

Os pontos da incisão cirúrgica eram retirados na primeira consulta ambulatorial após 1 semana da cirurgia, se ainda não cicatrizado nesse período, era postergado por mais uma semana. Os pacientes não realizaram fisioterapia ou qualquer tipo de reabilitação após o procedimento.

\subsection{Análise Estatística}

As variáveis clínicas e demográficas dos pacientes foram reportadas com uso de estatística descritiva. Variáveis quantitativas foram apresentadas através da mediana e de valores extremos. Variáveis qualitativas foram apresentadas através de números absolutos e frequências (\%).

A análise de variância (ANOVA) com medidas repetidas foi utilizada para avaliar mudanças nas escalas funcionais e de qualidade de vida ao longo do tempo. As pontuações nas escalas de avaliações clínicas foram representadas através da média e cada momento do tempo. Para os dados faltantes, foi realizada a imputação de dados através do método da última observação levada adiante.

O teste de Wilcoxon pareado foi utilizado para comparar a pontuação na escala radiográfica de Kellgren-Lawrence pré-operatória e após 48 semanas. 
Um valor de $P<0,05$ foi considerado estatisticamente significante. As análises estatísticas foram realizadas com o programa STATA (StataCorp, Texas, USA), versão 14.

\section{RESULTADOS}

Pelos critérios de seleção do estudo, no período de dezembro de 2014 a julho de 2017, realizamos o procedimento em 20 pacientes; destes, 18 completaram o tempo total de seguimento de 48 semanas, um paciente completou 24 semanas de seguimento e um paciente completou 6 semanas de seguimento.

Cinco (25\%) dos pacientes eram do sexo masculino e 15 (75\%) do sexo feminino, com mediana de idade de 59,5 anos, com idade máxima de 85 anos e mínima de 50 anos, com IMC mediano de 30,6 (extremos 24,2 - 40,1). O preenchimento com o substituto ósseo foi realizado no côndilo femoral medial em 11 joelhos e no planalto tibial medial em 12 joelhos. Nove joelhos eram direitos e 11 esquerdos, todos com alinhamento varo, com uma mediana de $4^{\circ}$ (Tabela 1 ). 
Tabela 1- Dados clínicos e antropométricos dos pacientes

\begin{tabular}{|c|c|c|c|c|c|c|c|}
\hline ID & Idade & Sexo & Lateralidade & $\begin{array}{c}\text { Local da } \\
\text { subcondroplastia }\end{array}$ & $\begin{array}{l}\text { Kellgren- } \\
\text { Lawrence }\end{array}$ & $\begin{array}{l}\text { Alinhamento do } \\
\text { membro em graus } \\
\text { (Varo+/Valgo-) }\end{array}$ & IMC \\
\hline 1 & 61 & $\mathrm{~F}$ & $\mathrm{D}$ & CFM & 1 & 3,1 & 30,0 \\
\hline 2 & 69 & M & $\mathrm{E}$ & PTM & 2 & 4,2 & 40,1 \\
\hline 3 & 58 & $\mathrm{~F}$ & E & CFM & 2 & 3,8 & 36,7 \\
\hline 4 & 85 & $\mathrm{~F}$ & $\mathrm{E}$ & CFM & 3 & 1,7 & 28,5 \\
\hline 5 & 70 & $\mathrm{~F}$ & $\mathrm{D}$ & CFM & 2 & 3,2 & 31,2 \\
\hline 6 & 58 & M & $\mathrm{D}$ & $\mathrm{CFM}+\mathrm{PTM}$ & 3 & 3,6 & 25,6 \\
\hline 7 & 50 & $\mathrm{~F}$ & $\mathrm{D}$ & $\mathrm{CFM}+\mathrm{PTM}$ & 1 & 6,4 & 28,3 \\
\hline 8 & 57 & $\mathrm{~F}$ & $\mathrm{E}$ & РТM & 2 & 6,8 & 33,7 \\
\hline 9 & 67 & M & $\mathrm{D}$ & PTM & 2 & 5,3 & 33,3 \\
\hline 10 & 57 & $\mathrm{~F}$ & $\mathrm{E}$ & PTM & 3 & 3,4 & 26,8 \\
\hline 11 & 52 & M & $\mathrm{D}$ & CFM & 1 & 2,3 & 31,2 \\
\hline 12 & 69 & $\mathrm{~F}$ & $\mathrm{E}$ & PTM & 1 & 2,9 & 34,0 \\
\hline 13 & 55 & $\mathrm{~F}$ & E & PTM & 3 & 5,3 & 29,4 \\
\hline 14 & 72 & $\mathrm{~F}$ & $\mathrm{D}$ & CFM & 2 & 4,8 & 26,6 \\
\hline 15 & 54 & $\mathrm{~F}$ & $\mathrm{E}$ & CFM & 3 & 3,3 & 26,0 \\
\hline 16 & 69 & $\mathrm{~F}$ & $\mathrm{E}$ & PTM & 2 & 6,4 & 28,0 \\
\hline 17 & 62 & $\mathrm{~F}$ & $\mathrm{D}$ & PTM & 3 & 6,7 & 31,2 \\
\hline 18 & 79 & $\mathrm{~F}$ & $\mathrm{E}$ & PTM & 1 & 4,3 & 33,6 \\
\hline 19 & 56 & $\mathrm{~F}$ & $\mathrm{E}$ & $\mathrm{CFM}+\mathrm{PTM}$ & 3 & 2,1 & 31,2 \\
\hline 20 & 50 & $\mathrm{M}$ & $\mathrm{D}$ & CFM & 1 & 5,7 & 24,2 \\
\hline Mediana & 59,50 & & & & 2 & 4,0 & 30,6 \\
\hline $\begin{array}{l}\text { *CFM: C } \\
* * \mathrm{D}: \mathrm{Dir} \\
* * * \mathrm{E}: \mathrm{Es} \\
* * * * \mathrm{~F}: \mathrm{F} \\
* * * * * \mathrm{M}: \\
* * * * * * \mathrm{P}\end{array}$ & $\begin{array}{l}\text { ndilo } \mathrm{F} \\
\text { ito } \\
\text { uerdo } \\
\text { minino } \\
\text { Mascul } \\
\Gamma \mathrm{M} \cdot \mathrm{Pl}\end{array}$ & emora & Medial & & & & \\
\hline
\end{tabular}

Nas avaliações pela escala de KOOS, houve melhora significativa nos critérios de sintomas, dor, função diária, função esportiva e qualidade de vida. A avaliação pela escala de IKDC subjetivo apresentou uma melhora significativa no período de seguimento, assim como a EVA de dor (Tabela 2; Gráficos 1, 2 e 3). Pela escala de IKDC subjetivo, 17 (85\%) pacientes apresentaram melhora da pontuação (Gráfico 4). Da mesma forma, pela EVA de dor, $17(85 \%)$ tiveram melhora superior a 2 pontos (Gráfico 5). 
Tabela 2 - Média das avaliações clínicas pelas escalas de KOOS (dentro dos seus subgrupos de sintomas, dor, função diária, função esportiva e qualidade de vida), IKDC subjetivo e EVA de dor

\begin{tabular}{lcccccccc}
\hline & & 1 & 3 & 6 & 12 & 24 & 48 & \\
Escalas de avaliação clínica & Pré-op & Sem & Sem & Sem & Sem & Sem & Sem & $\mathrm{p}^{1}$ \\
\hline KOOS Sintomas & 45,0 & 64,1 & 67,1 & 72,4 & 69,6 & 77,6 & 84,4 & $\mathrm{p}<0,001$ \\
KOOS Dor & 40,7 & 72,4 & 70,6 & 69,7 & 68,3 & 79,9 & 79,4 & $\mathrm{p}<0,001$ \\
KOOS Função Diária & 47,1 & 73,8 & 75,1 & 74,9 & 72,9 & 81,3 & 85,9 & $\mathrm{p}<0,001$ \\
KOOS Função Esportiva & 6,8 & 21,3 & 31,3 & 28,0 & 26,8 & 35,8 & 28,8 & $\mathrm{p}=0,006$ \\
KOOS Qualidade de Vida & 20,3 & 47,5 & 53,1 & 47,2 & 47,5 & 53,4 & 62,2 & $\mathrm{p}<0,001$ \\
IKDC Subjetivo & 28,4 & 52,5 & 54,3 & 53,7 & 50,6 & 59,8 & 59,1 & $\mathrm{p}<0,001$ \\
EVA de dor & 7,0 & 3,3 & 3,2 & 3,0 & 3,0 & 2,7 & 2,5 & $\mathrm{p}<0,001$ \\
\hline
\end{tabular}

*Pré-op: Pré-operatório

**Sem: Semanas

${ }^{1}$ ANOVA para medidas repetidas

Gráfico 1- Evolução da média da escala de KOOS em seus diferentes subgrupos (sintomas, dor, função diária, função esportiva e qualidade de vida), no período de seguimento

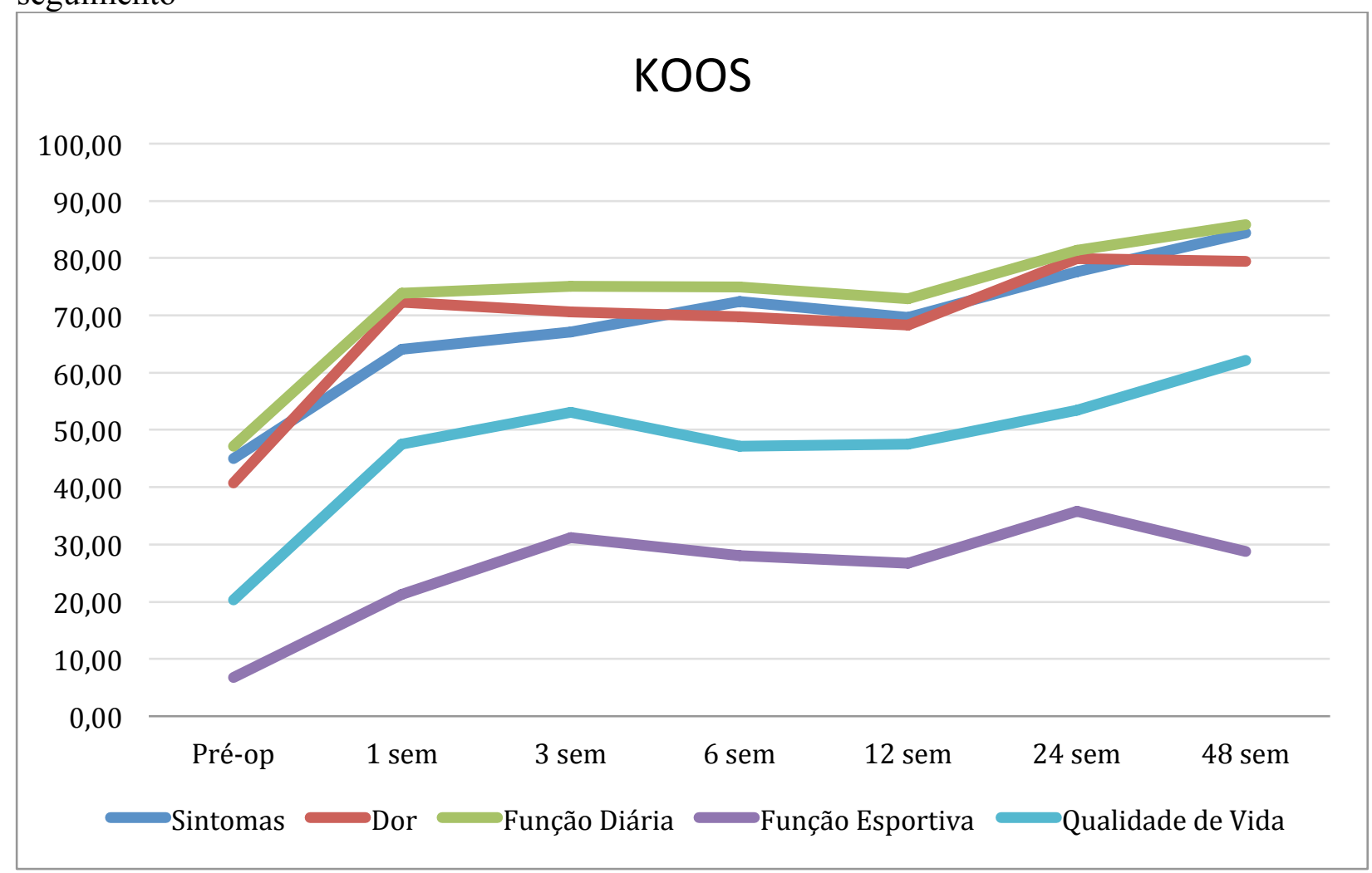

\footnotetext{
* sem: semanas

**Pré-op: Pré-operatório
} 
Gráfico 2 - Evolução da média da escala de IKDC Subjetivo no período de seguimento

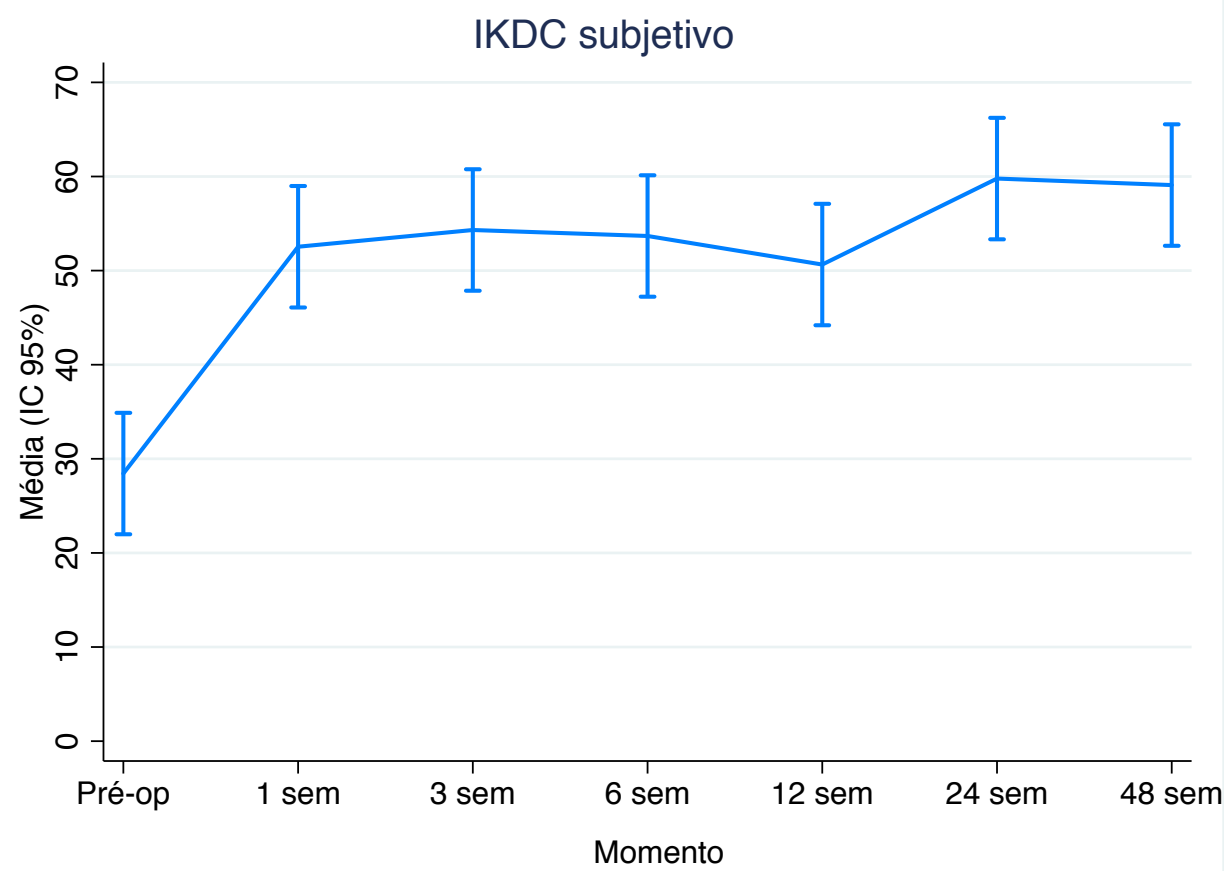

* IC: Intervalo de confiança

** sem: semanas

****Pré-op: pré-operatório

Gráfico 3 - Evolução da média da escala visual analógica de dor no período de seguimento

EVA

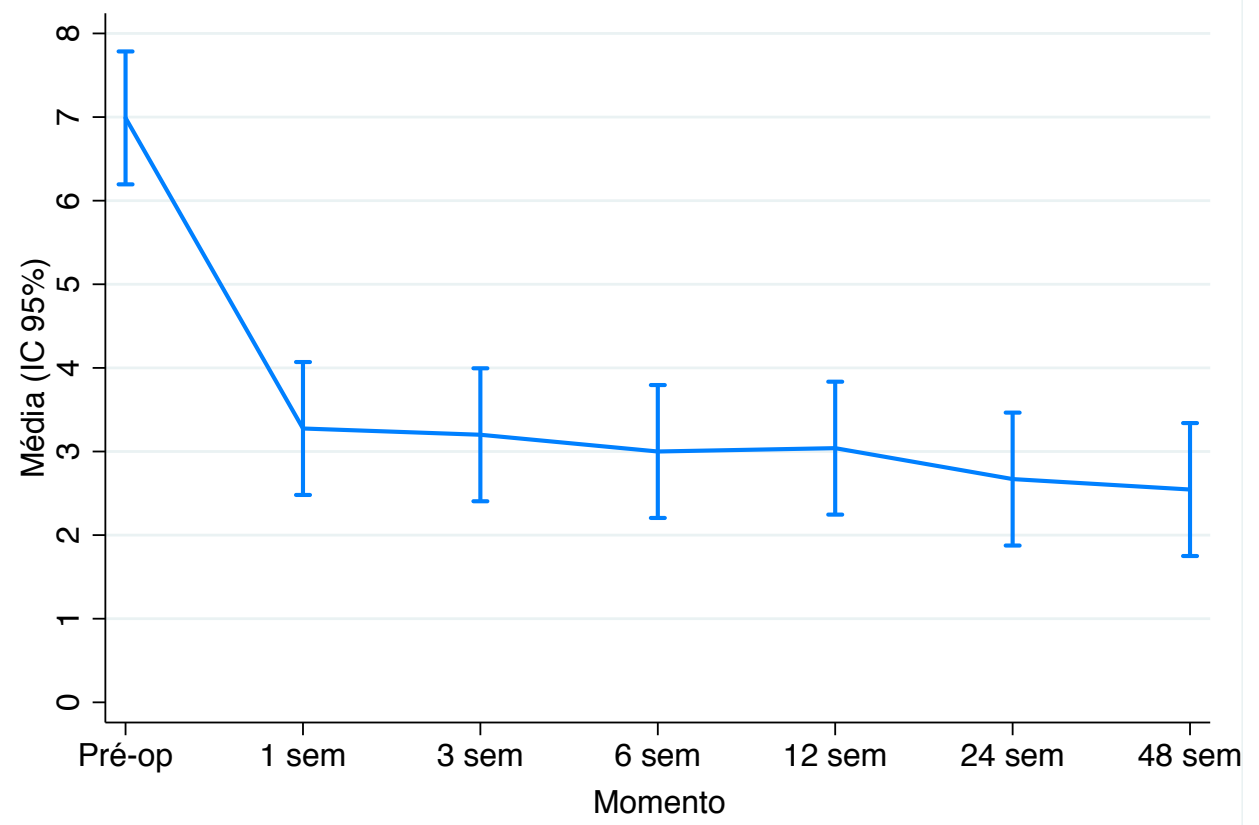

*Pré-op: Pré-operatório

**sem: Semanas

***IC: Intervalo de confiança 
Gráfico 4 - Porcentagem de pacientes com melhora da escala de IKDC subjetivo ao final do seguimento

\section{IKDC Subjetivo}

- Melhoraram $\quad$ Pioraram

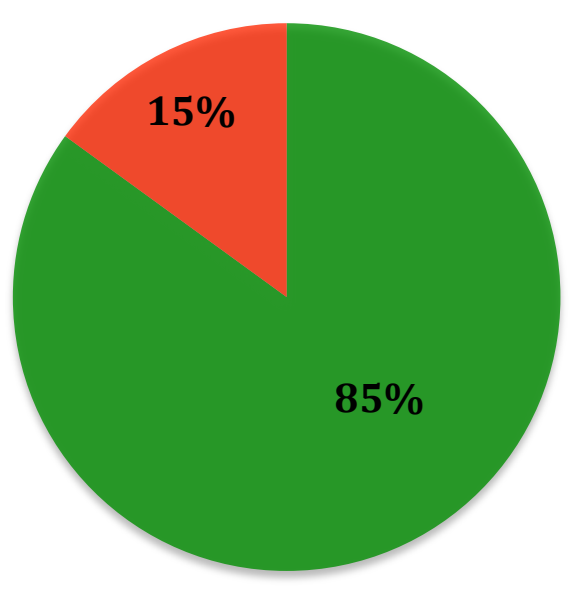

Gráfico 5 - Porcentagem de pacientes com melhora maior que 2 pontos pela EVA de dor ao final do seguimento

\section{EVA Dor}

- Melhoraram $>2$ pontos Melhoraram $\leq 2$ pontos

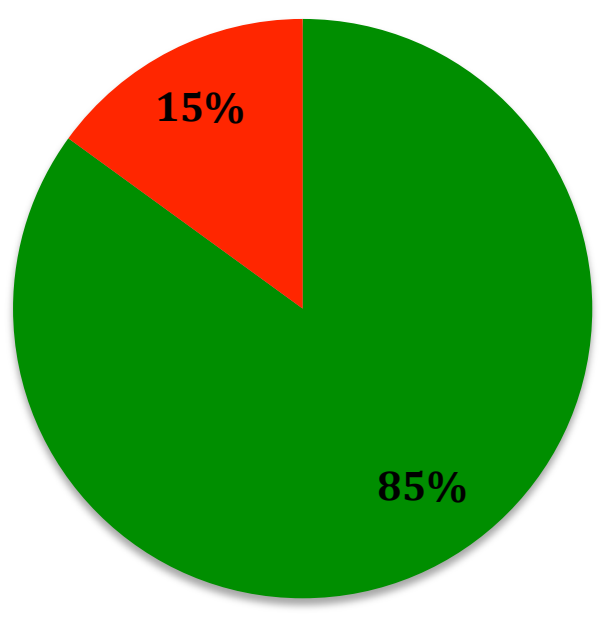


A avaliação da qualidade de vida pela escala de SF-36 apresentou melhora significativa na capacidade funcional, aspectos físicos, vitalidade, estado geral de saúde, aspectos sociais, aspectos emocionais e saúde mental. Apenas o subgrupo da dor não apresentou melhora significativa (Tabela 3).

Tabela 3 - Média das avaliações da qualidade de vida pela escala SF-36v1 dentro dos seus subgrupos de capacidade funcional, aspectos físicos, dor, estado geral de saúde, vitalidade aspectos sociais, aspectos emocionais e saúde mental

\begin{tabular}{lcccc}
\hline SF-36 & Pré-op & 24 Sem & 48 Sem & $\mathrm{p}^{1}$ \\
\hline Capacidade Funcional & 35,38 & 57,69 & 71,92 & $\mathrm{p}<0,001$ \\
Aspectos Físicos & 17,31 & 42,31 & 80,77 & $\mathrm{p}<0,001$ \\
Dor & 59,85 & 70,15 & 69,38 & $\mathrm{p}=0,398$ \\
Estado Geral de Saúde & 66,15 & 68,77 & 79,69 & $\mathrm{p}=0,015$ \\
Vitalidade & 52,69 & 58,46 & 76,92 & $\mathrm{p}=0,017$ \\
Aspectos Sociais & 62,38 & 69,54 & 86,54 & $\mathrm{p}<0,003$ \\
Aspectos Emocionais & 30,77 & 61,54 & 84,62 & $\mathrm{p}<0,001$ \\
Saúde Mental & 60,92 & 64,62 & 81,54 & $\mathrm{p}=0,019$ \\
\hline
\end{tabular}

*Pré-op: Pré-operatório

**sem: semanas

${ }^{1}$ ANOVA para medidas repetidas

Antes do procedimento seis pacientes tiveram classificação radiográfica de Kellgren-Lawrence grau I, sete pacientes, grau II e sete pacientes, grau III. Dos 17 pacientes com radiografias pós-operatórias, cinco apresentaram piora na classificação ao final do seguimento. A pontuação na escala radiográfica de Kellgren-Lawrence após 48 semanas do procedimento foi significativamente pior que a pontuação préoperatória $(Z=-2,236, p=0,025)$. Não houve, porém, relação da piora radiográfica com a piora da escala funcional de IKDC ou com a EVA de dor. Todos os pacientes com piora da classificação radiográfica tiveram uma melhora de pelo menos dois pontos na escala de dor e também uma melhora na escala funcional de IKDC (Tabela 4). 
Tabela 4 - Progressão da artrose pela classificação de Kellgren-Lawrence e diferença das escalas de IKDC e EVA de dor do período pré-operatório para o seguimento final com 48 semanas

\begin{tabular}{cccccc}
\hline \multicolumn{7}{c}{ K-L } & K-L 48 & Evolução do & & \\
ID & Pré-op & Sem & K-L & $\Delta$ EVA & $\Delta$ IKDC \\
\hline 1 & 1 & 2 & Pior & -6 & 24,1 \\
2 & 2 & 2 & Igual & -6 & $-9,2$ \\
3 & 3 & 3 & Igual & -4 & 33,4 \\
4 & 3 & 3 & Igual & -9 & 28,7 \\
5 & 2 & 3 & Pior & -7 & 44,9 \\
6 & 3 & 3 & Igual & $-3,6$ & $-5,75$ \\
7 & 1 & 2 & Pior & $-2,3$ & 36,8 \\
8 & 2 & 2 & Igual & $-7,4$ & 61 \\
10 & 3 & 3 & Igual & $-7,6$ & 45,96 \\
13 & 2 & 2 & Igual & $-2,1$ & 16,1 \\
14 & 2 & 2 & Igual & $-7,1$ & 48,36 \\
15 & 3 & 3 & Igual & $-2,1$ & 28,7 \\
16 & 2 & 3 & Pior & $-5,8$ & 75,9 \\
17 & 3 & 3 & Igual & $-4,5$ & $-10,36$ \\
18 & 1 & 1 & Igual & $-6,2$ & 7,2 \\
19 & 3 & 3 & Igual & $-2,1$ & 25,32 \\
20 & 1 & 2 & Pior & $-3,7$ & 28,8 \\
\hline
\end{tabular}

* K-L: Kellgren-Lawrence

**Pré-op: Pré-operatório

*** Sem: semanas

$* * * * \Delta:$ Diferença

Das 20 ressonâncias magnéticas iniciais, em 8 (40\%) observou-se edema grau 1, 4 (20\%), edema grau 2 e 8 (40\%), edema grau 3. Cistos subcondrais foram encontrados em 6 (30\%) joelhos, fraturas do osso subcondral em $12(60 \%)$ e impacção da superfície articular em $6(30 \%)$. Doze ressonâncias magnéticas realizadas após 48 semanas de seguimento foram avaliadas, sendo que 3 (25\%) não tinham mais edema, $7(58,3 \%)$ tinham edema grau 1 e $2(16,7 \%)$, edema grau 2 . Seis $(50 \%)$ pacientes apresentaram redução do edema. Impacções da superfície articular foram encontradas em 7 (58,3\%) joelhos, sendo que em 5 (41,6\%) joelhos houve piora da impacção, em $6(50 \%)$ não houve alteração e em 1 (8,3\%) houve redução da impacção. (Tabela 5). 
Tabela 5 - Avaliações dos exames de ressonância magnética pré-operatórios e após as 48 semanas de seguimento.

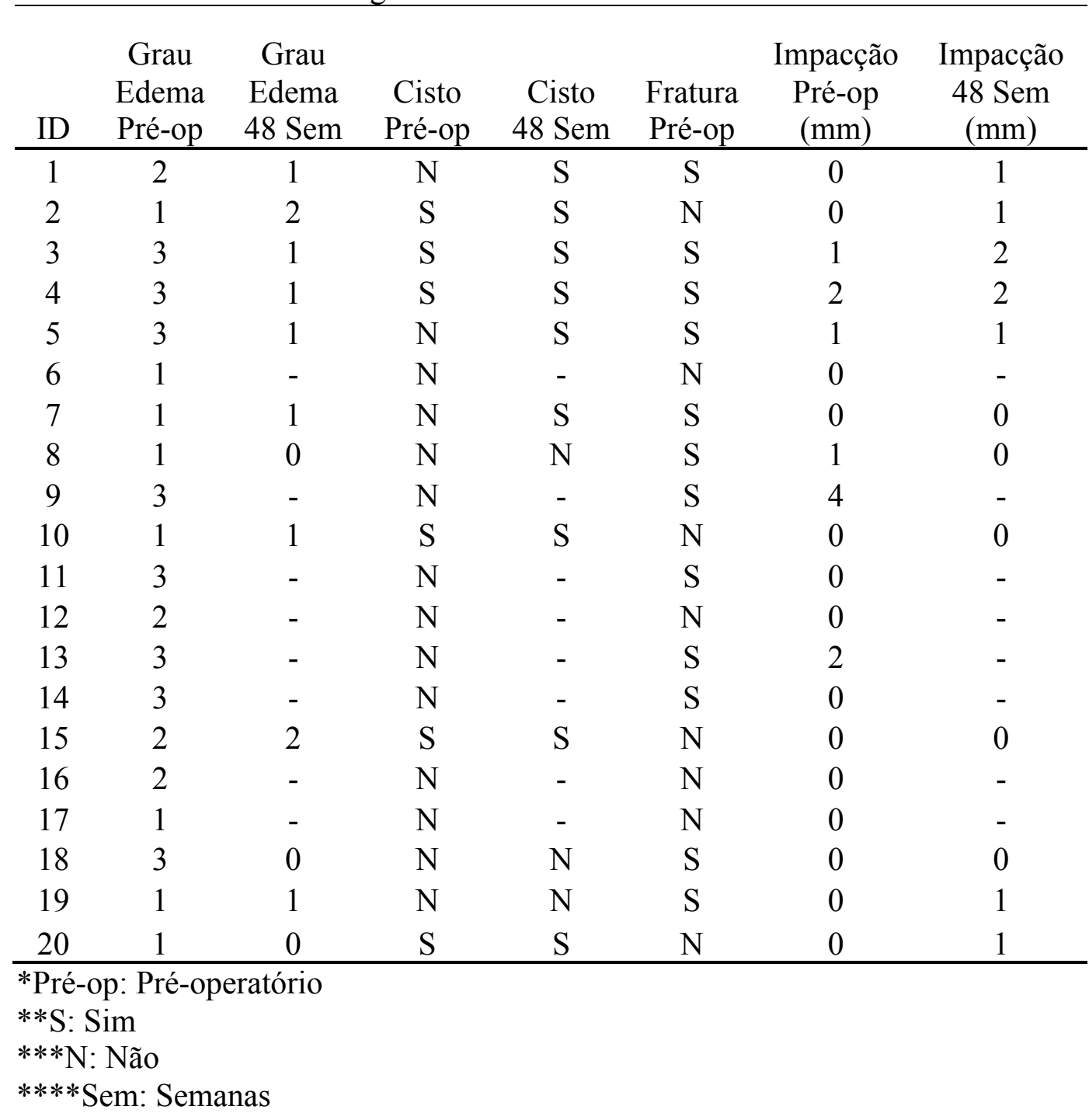

Como complicações, dois pacientes apresentaram extravasamento do substituto ósseo, sendo um através de uma perfuração da cortical oposta pela ponta da cânula na região anterolateral da tíbia e outro no ponto de entrada da cânula da região supracondiliana lateral do fêmur. O primeiro paciente apresentou desconforto no ponto de extravasamento, sendo necessária nova cirurgia, após três meses da subcondroplastia, para retirada do material extravasado, com melhora completa após a retirada do material. Já o segundo paciente apresentou moderado desconforto pelo período de uma semana, próximo ao ponto de entrada da cânula, desaparecendo após 
esse período. Através do seguimento radiográfico foi observado a reabsorção do material extravasado (Figura 7).

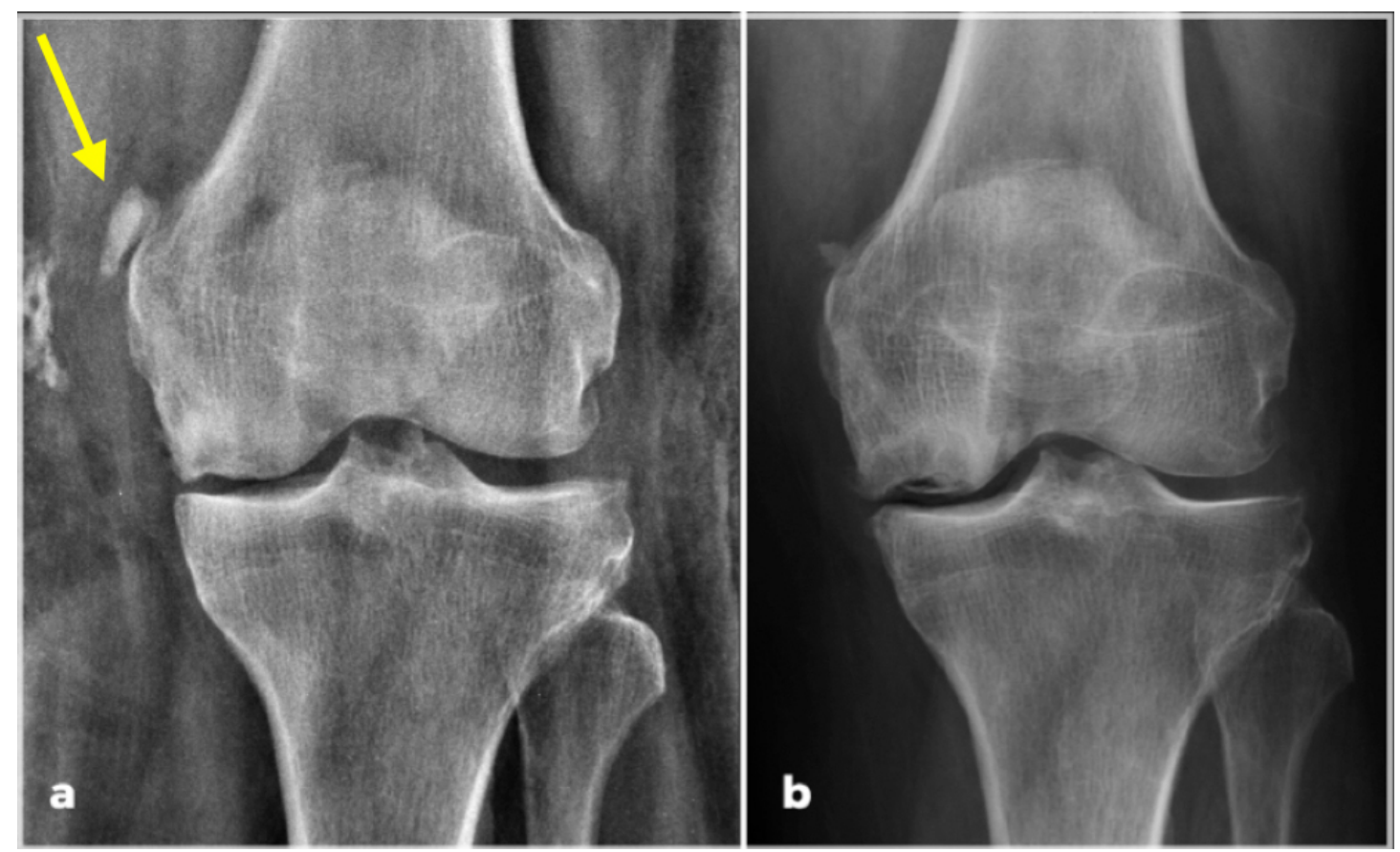

Figura 7 - Radiografias em incidência anteroposterior do joelho esquerdo do paciente de identificação 3, que apresentou extravasamento do enxerto na região supracondiliana medial a) Radiografia imediatamente após a cirurgia com seta em amarelo apontando a imagem do material extravasado; b) Radiografia após 48 semanas de seguimento com reabsorção do material extravasado

Todos os pacientes conseguiram deambular, sem apoio adicional, já no primeiro dia após o procedimento.

\section{DISCUSSÃO}

Obtivemos, com essa série de casos, resultados positivos com o uso da técnica cirúrgica de subcondroplastia no tratamento de edema medular ósseo no joelho. Foi possível realizar a técnica com sucesso, conseguindo injetar o substituto ósseo nas áreas acometidas, obtendo resultados significantes de melhora clínica e de desempenho funcional dos pacientes. Principalmente, se destacou a redução 
importante da dor em curto espaço de tempo. Esses resultados vão ao encontro da literatura atual, na qual a técnica testada em séries de casos apresenta resultados clínicos de melhora expressiva ${ }^{56,58,62,65}$, com exceção do estudo de Chatterjee et al. ${ }^{59}$.

Importante também é a manutenção dos bons resultados durante o período de seguimento de 48 semanas. Demonstrou-se a capacidade da técnica de gerar um alívio de sintomas duradouro, além do tempo de reabsorção do substituto ósseo, o que talvez ocorra por uma remodelação da estrutura óssea, evitando a recidiva de lesões nas áreas tratadas. Porém, ainda são necessários estudos histológicos e de maior seguimento, para completa compreensão dos efeitos da subcondroplastia e seus resultados em longo prazo.

Outro achado importante é a progressão radiográfica da osteoartrite de cinco pacientes apesar de uma melhora funcional de sintomas. Tal achado corrobora o conhecido fato de uma dissociação clinicorradiológica na osteoartrite do joelho e perpetua um questionamento sobre a origem da dor desses pacientes. Acreditamos que esses casos demonstram a capacidade da subcondroplastia em tratar o componente de dor óssea, melhorando a dor, a função e a qualidade de vida, mesmo que não interrompa a história natural da degeneração da articulação.

Estudos nos últimos vinte anos vêm demonstrando de forma clara a importância do osso subcondral para a longevidade da articulação. O edema ósseo medular ou lesão óssea medular é um sinal de alteração ou mesmo falha do osso subcondral, tendo uma importante correlação com os sintomas do paciente e a progressão do processo degenerativo do joelho ${ }^{12,14-16,18,24,27-29}$.

No presente estudo a avaliação do osso subcondral pelo exame de ressonância magnética demonstrou uma boa preservação estrutural. Apesar de cinco pacientes 
apresentarem um aumento na progressão da impacção, nenhum paciente apresentou impacção maior que $2 \mathrm{~mm}$ após a subcondroplastia, sendo este um desvio aceitável no tratamento de lesões articulares. A aferição de uma alteração de apenas $1 \mathrm{~mm}$ também é limítrofe quanto à sensibilidade de seu método, podendo ocorrer devido a uma variação do método e não de uma verdadeira alteração do osso subcondral.

Outro fator positivo foi que apesar de mais da metade dos pacientes ter uma linha de fratura no exame inicial, nenhuma das avaliações finais apresentou destacamento da superfície articular. Já a avaliação da área de alto sinal que apresentou uma redução em sete dos pacientes, apesar de ser algo desejado e positivo, é um resultado esperado independentemente de uma intervenção cirúrgica, devido à resolução do quadro agudo e à redução da reação local após 48 semanas.

A subcondroplastia, devido a seus bons resultados, surge como uma interessante opção de tratamento para essas lesões com uma proposta de estruturação mecânica e biológica da região, adicionando a vantagem de ser uma técnica minimamente invasiva e com baixa morbidade para o paciente ${ }^{56,58,62}$.

Atualmente o edema medular ósseo sintomático é tratado com analgésicos, fisioterapia e principalmente com a redução de carga mecânica na articulação afetada, sendo necessários períodos de três a oito semanas de uso de muletas, com retirada completa da carga, para melhora dos $\operatorname{sintomas}^{35}$. O uso de suportes da marcha, para restrição de carga, muitas vezes é inviável em pacientes idosos que possuem limitações de força e função dos membros superiores. Por isso, muitas vezes estes não aderem à recomendação de restrição de carga ou ficam restritos à cadeira de rodas ou ao repouso na cama. Tal restrição de atividade, de forma tão intensa, pode ter consequências severas para o sistema musculoesquelético e para funcionalidade do idoso, sendo de difícil recuperação ${ }^{71}$. Por outro lado, ao não se proteger o 
compartimento acometido, alguns edemas ósseos podem evoluir de forma bastante desfavorável com colapso ou até destacamento da superfície osteocondral.

Outra opção de tratamento para pacientes com uma osteoartrite mais avançada do joelho, associada a edema medular ósseo, é a artroplastia total do joelho. Porém, esta é uma cirurgia de grande porte, com maior morbidade e maiores riscos ${ }^{72,73}$. Riscos que muitas vezes contraindicam sua realização em pacientes com comorbidades. A artroplastia, por ser uma cirurgia de substituição da articulação, é definitiva e tem uma sobrevida, podendo ser necessários procedimentos ainda mais complexos de revisão, principalmente em pacientes abaixo dos 60 anos em uma população com expectativa de vida em ascensão. Dessa forma, procedimentos de preservação da articulação, como a subcondroplastia, ganham importância quando se leva em consideração que muitos dos edemas medulares ósseos ocorrem em pacientes com menos de 60 anos, sendo metade dos pacientes na amostra deste estudo.

Tais fatores tornam atraente a possibilidade de um tratamento de baixa morbidade, que possibilita uma melhora de sintomas e recuperação funcional mais rápida e com menos restrições. Dessa forma, em nossa visão, a subcondroplastia teria boa indicação para pacientes com fraturas de insuficiência do osso subcondral, na qual há um dano estrutural claro do osso subcondral. Especialmente em pacientes com menos de 60 anos de idade, na qual procedimentos que preservem a articulação são de maior interesse. Porém, também seria uma alternativa adequada para pacientes mais idosos, com alto risco cirúrgico e menor demanda funcional, nos quais o alívio dos sintomas, mesmo que parcial, com procedimentos de menor morbidade pode ter significantes ganhos funcionais.

No entanto, ainda existe uma grande indefinição na literatura sobre os diferentes padrões de imagem, sem um consenso da classificação das lesões genericamente 
denominadas como edema medular ósseo. Tal situação acaba por limitar dois aspectos importantes. Primeiro, há um conhecimento pouco preciso sobre a história natural do edema medular ósseo, pois a maioria dos estudos não diferenciam condições diferentes, impossibilitando a definição precisa de tempo de evolução, fatores de prognóstico, sintomas e consequências para a articulação acometida. Segundo, consequentemente, também não existem boas avaliações das diferentes propostas de tratamento, impossibilitando qualquer fluxograma ou definição de indicação das diferentes terapias.

Tal situação tem impacto direto na avaliação da subcondroplastia e nos resultados deste estudo. Os estudos que avaliam a técnica de injeção de substituto ósseo nas áreas de edema medular ósseo não fazem uma distinção sobre os diferentes padrões ou possíveis causas para as lesões tratadas, impossibilitando uma melhor definição de indicação da técnica e prejudicando as avaliações de resultados, já que não há uma análise distinta entre as diferentes condições que podem ser consideradas como edemas medulares ósseos. Por isso, apesar de resultados semelhantes em alguns estudos, é importante a definição de uma classificação e terminologia mais detalhada e clara para as lesões de edema ósseo medular, buscando uma melhor padronização de classes e etiologias das diferentes imagens. Sem tal definição, a avaliação e comparação de diferentes tratamentos se torna difícil e pouco fidedigna, pois a base de cada estudo pode estar em patologias diferentes. Por essa razão, também são necessários estudos que busquem avaliar a patogênese dos diferentes padrões de edema ósseo. Atualmente ainda existem poucos estudos correlacionando as alterações na ressonância magnética com achados histológicos e os existentes não buscam diferenciação entre padrões de imagem, considerando todos as lesões de edema ósseo como uma condição única $5,42,47,49$. 
Acreditamos que a divisão sugerida por Kon et al. ${ }^{2}$ possa ter uma melhor relação com a fisiopatologia e prognóstico das diferentes lesões, conseguindo assim auxiliar no manejo do tratamento de cada classe. Ao determinarem um grande grupo inicial de lesões traumáticas, os autores já separam um distinto grupo de condições agudas e de gênese mecânica externa, com características completamente diferentes das demais lesões. A segunda divisão proposta em lesões reversíveis e não reversíveis direciona o tratamento, uma vez que lesões reversíveis devem ser em princípio tratadas de forma conservadora, com expectativa de um bom resultado. Já lesões não reversíveis exigem tratamentos mais agressivos, na tentativa de interromper a progressão da lesão e consequentemente uma rápida degeneração da articulação.

O presente estudo apresenta como limitações um número de pacientes ainda pequeno e a ausência de um grupo controle para uma melhor avaliação da eficácia da técnica de subcondroplastia. Porém, acreditamos que a prevalência de edema medular ósseo sintomático, com alterações que justifiquem a injeção de substituto ósseo, seja limitada, o que justifica a dificuldade na ampliação do $\mathrm{N}$ deste estudo. Uma segunda limitação é o tempo de seguimento que mesmo com 48 semanas, ainda é curto para uma avaliação mais adequada do efeito na progressão da osteoartrite. No entanto, tais limitações não afetam a importância das conclusões alcançadas.

Atualmente, o estudo tem sua importância como um passo inicial em uma linha de pesquisa do uso de injeções ósseas percutâneas para o tratamento das doenças que afetam o osso subcondral. Este é o primeiro trabalho na área no Brasil, tornando possível a realização da técnica de forma segura e eficiente em seu objetivo, mostrando resultados clínicos semelhantes ao da literatura existente, mesmo com utilização de materiais diferentes dos artigos iniciais. Porém, ainda são necessários estudos adicionais com o objetivo de uma melhor compreensão das doenças do osso 
subcondral, aprimoramento das indicações da subcondroplastia e melhor análise dos resultados da técnica com a possibilidade de grupos controles de diferentes desenhos, uma vez que não existe um tratamento padrão-ouro para as lesões de edema ósseo medular.

Como perspectivas futuras para subcondroplastia, acreditamos em uma evolução dos procedimentos de injeções ósseas para o tratamento de lesões do osso subcondral, com o desenvolvimento de novos produtos ainda mais especializados e com maior potencial de tratamento das patologias nessa região. O procedimento atualmente ainda tem uma ação biológica reduzida. Além da atual estruturação mecânica, poderá ser possível a associação com drogas que tenham uma ação mais ativa na resolução dessas lesões. Nesta mesma linha, acreditamos em uma evolução no estudo do osso subcondral, já que atualmente é clara a participação deste na etiologia de parte das osteoartrites do joelho. O primeiro passo deve ser a definição de padrões de alterações do osso subcondral, entendendo melhor as diferentes etiologias será possível o desenvolvimento de novas modalidades e fluxos de tratamento. Dessa forma, poderemos talvez tratar o osso subcondral em uma fase inicial, tentando evitar a falência e degeneração da articulação, assim como atualmente tratamos as lesões da cartilagem, menisco e ligamentos.

\section{CONCLUSÃO}

Os resultados do presente estudo mostram que a técnica de subcondroplastia realizada com enxertos adequados é segura e associada à melhora de dor e 
desempenho funcional clinicamente significativo. A melhora clínica pela redução de dor em mais de dois pontos na EVA, associada à melhora nas atividades diárias e qualidade de vida dos pacientes ocorre em curto prazo de seguimento e se sustenta em médio prazo, até 48 semanas. Ao final do seguimento não se observou uma progressão significativa da degeneração osso subcondral. 


\section{ANEXOS}

Anexo 1- Carta de aprovação da CAPPESQ

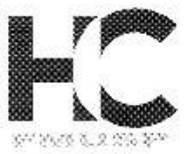

Hospital das Clínicas da FMUSP

Comissão de Ética para Análise de Projetos de Pesquisa - CAPPesq

\section{PROJETO DE PESQUISA}

Título: TRATAMENTO DAS LESÕES DE EDEMA MEDULAR ÓSSEO DO JOELHO PELA TÉCNICA DE SUBCONDROPLASTIA

Pesquisador Responsável: Marco Kawamura Demange Versão: 1

Pesquisador Executante: Marcelo Batista Bonadio CAAE: 37392614.9.0000.0068

Coautores: Camilo Partezani Helito, Marcia Uchoa de Rezende, José Ricardo Pécora, Gilberto

Luis Camanho

Instituição: HCFMUSP

Departamento: ORTOPEDIA E TRAUMATOLOGIA

\section{PARECER CONSUBSTANCIADO DO CEP}

Registro on-line: 12479

Número do Parecer: 859.206

Data da Relatoria: 05/11/2014

Apresentaçăo do Projeto: Este é um projeto para pacientes com lesões degenerativas do joelho.

Objetivo da Pesquisa: Visa testar o benefício da injeção de indutor de matriz óssea para estimular a osteogênse subcondral.

Avaliaçăo dos Riscos e Benefícios: Há riscos moderados porém encontram-se equacionados no protocolo.

Comentários e Considerações sobre a Pesquisa: O projeto é atual e poderá beneficiar esta enfermidade de altíssima prevalência.

Consideraçöes sobre os Termos de apresentação obrigatória: O TCLE é sintético, porém aceitável.

Recomendações: Não há.

Conclusర̃es ou Pendências e Lista de Inadequações: Não há pendências.

Situação do Parecer: Aprovado.

Necessita Apreciaçäo da CONEP: Não.

Considerações Finais a critério do CEP: Em conformidade com a Resolução CNS n0 466/12 cabe ao pesquisador: a) desenvolver o projeto conforme delineado; b) elaborar e apresentar relatórios parciais e final; c)apresentar dados solicitados pelo CEP, a qualquer momento; d) manter em arquivo sob sua guarda, por 5 anos da pesquisa, contendo fichas individuais e todos os demais documentos recomendados pelo CEP; e) encaminhar os resultados para publicaçăo, com os devidos créditos aos pesquisadores associados e ao pessoal técnico participante do projeto; f) justificar perante o CEP interrupçăo do projeto ou a năo publicação dos resultados.

São Paulo, 05 de Novembro de 2014

$$
\begin{gathered}
\text { Prof. Dr. Alfredo José Mansur } \\
\text { Coordenador } \\
\text { Comissão de Ética para Análise } \\
\text { de Projetos de Pesquisa - CAPPesq }
\end{gathered}
$$

Rua Dr. Ovídio Pires de Campos, 225 - Prédio da Administraçăo - 5a andar

$$
\text { CEP 05403-010 - São Paulo - SP. }
$$

5511 2661-7585 - 5511 2661-6442 ramais: 16, 17, 18 | marcia.carvalho@hc.fm.usp.br 
Anexo 2 - Termo de consentimento livre esclarecido

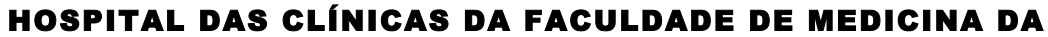 UNIVERSIDADE DE SÃO PAULO-HCFMUSP}

TERMO DE CONSENTIMENTO LIVRE E ESCLARECIDO

DADOS DE IDENTIFICAÇÃO DO SUJEITO DA PESQUISA OU RESPONSÁVEL LEGAL

1. NOME:

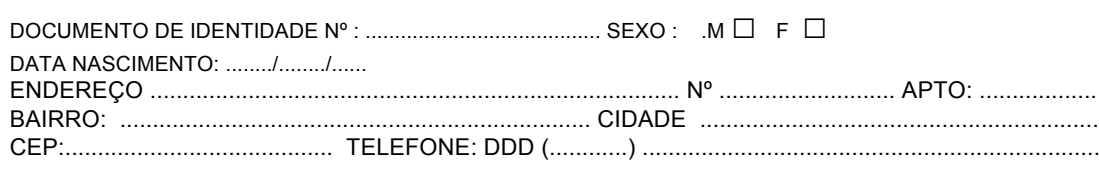

1. TÍTULO DO PROTOCOLO DE PESQUISA

Tratamento das lesões de edema medular ósseo do joelho pela técnica de Subcondroplastia

PESQUISADOR : Dr. Marco Kawamura Demange CARGO/FUNÇÃO: Chefe Grupo Joelho INSCRIÇÃO CONSELHO REGIONAL Nº UNIDADE DO HCFMUSP: IOT HC-FMUSP 3. AVALIAÇÃO DO RISCO DA PESQUISA:

$\begin{array}{ll}\text { RISCO MÍNIMO } & \text { RISCO MÉdIO } X \\ \text { RISCO BAIXO } & \text { RISCO MAIOR } \square\end{array}$

4.DURAÇÃO DA PESQUISA : 36 meses 


\section{HOSPITAL DAS CLÍNICAS DA FACULDADE DE MEDICINA DA UNIVERSIDADE DE SÃO PAULO-HCFMUSP}

Você esta com uma lesão óssea no joelho. Para tratamento da mesma você será submetido a um tratamento cirúrgico em nosso instituto.

Existem várias modalidades de tratamento para a lesão óssea que você apresenta.

Uma técnica foi desenvolvida no intuito de melhorar seus sintomas e diminuir a progressão da sua doença.

Nos do grupo de joelho convidamos você a fazer parte de um projeto de pesquisa que fará a utilização dessa técnica com uso dos documentos de seu prontuário arquivado no IOTHCFMUSP e documentação fotográfica de sua cirurgia.

Você terá acesso aos profissionais responsáveis pela pesquisa para esclarecimento de eventuais dúvidas em qualquer etapa do estudo. O principal investigador é o Dr. Marco Kawamura Demange, que pode ser encontrado no endereço Rua Dr. Ovídio Pires de Campos, 333, Telefone (11) 3069-6912. Se você tiver alguma consideração ou dúvida sobre a ética da pesquisa, entre em contato com o Comitê de Ética em Pesquisa (CEP) - Rua Ovídio Pires de Campos, $225-5^{\circ}$ andar - tel: 3069-6442 ramais $16,17,18$ ou 20, FAX: 3069-6442 ramal 26 E-mail: cappesq@hcnet.usp.br

É garantida a liberdade da retirada de consentimento a qualquer momento e deixar de participar do estudo, sem qualquer prejuízo à continuidade de seu tratamento na Instituição; 
As informações obtidas serão analisadas em conjunto com outros pacientes, não sendo divulgado a identificação de nenhum paciente;

Você tem o direito de ser mantido atualizado sobre os resultados parciais das pesquisas.

Não haverá despesas para você em qualquer fase do estudo, incluindo exames e consultas. Também não há compensação financeira relacionada à sua participação. Se existir qualquer despesa adicional, ela será absorvida pelo orçamento da pesquisa.

Compromisso do pesquisador de utilizar os dados e o material coletado somente para esta pesquisa. 


\section{hOSPITAL dAS CLÍNICAS DA FACULdAde de MEdicina da UNIVERSIDAdE dE SÃO PAULO-HCFMUSP}

Ao aceitar fazer parte desta pesquisa, o paciente (você) continuará recebendo a assistência médica do mesmo modo que já recebe e não terá vantagens em relação aos outros pacientes, do mesmo modo que se recusar entrar na pesquisa também não será prejudicado pela decisão.

Sempre que tiver qualquer dúvida em relação ao estudo, poderá a qualquer momento perguntar para um dos médicos de nossa equipe que esclarecerá as questões da melhor forma que puder.

Se por qualquer motivo você desistir de participar da pesquisa, deve avisar um dos médicos do grupo de joelho e sua decisão será respeitada. Ressaltamos ainda que se sua opção for desistir ou não aceitar entrar na pesquisa, não haverá qualquer tipo de problemas no seu acompanhamento, ou seja, continuará sendo tratada como qualquer outro paciente do nosso grupo, quer ele participe de uma pesquisa ou não.

Em nenhum momento usaremos seu nome, dados pessoais ou fotos que revelem sua identidade em trabalhos, publicações de revistas ou aulas e cursos de medicina.

Qualquer outra dúvida, por favor procurar um dos médicos da equipe de joelho do HC, ou se não conseguir nos encontrar, uma de nossas assitentes sociais.

Garantia de acesso: em qualquer etapa do estudo, você terá acesso aos profissionais responsáveis pela pesquisa para esclarecimento de eventuais dúvidas. O principal investigador é - Dr Marco Kawamura Demange, que pode ser encontrado no Instituto de Ortopedia e Traumatologia do Hospital das Clínicas da Faculdade de Medicina da USP.

TEL: 3069-6815, 3069-6818

Se vocè tiver alguma consideraçäo ou dúvida sobre a ética da pesquisa, entre em contato com o Comitê de Ética em Pesquisa (CEP) - Rua Ovídio Pires de Campos, 225 - $5^{\circ}$ andar - tel: 3069-6442 ramais 16, 17, 18 ou 20, FAX: 3069-6442 ramal 26 - E-mail: cappesq@hcnet.usp.br É garantida a liberdade da retirada de consentimento a qualquer momento e deixar de participar do estudo, sem qualquer prejuízo à continuidade de seu tratamento na Instituição; Direito de confidencialidade - As informações obtidas seräo analisadas em conjunto com outros pacientes, não sendo divulgado a identificação de nenhum paciente; Direito de ser mantido atualizado sobre os resultados parciais das pesquisas, quando em estudos abertos, ou de resultados que sejam do conhecimento dos pesquisadores; Despesas e compensações: não há despesas pessoais para o participante em qualquer fase do estudo. 
incluindo exames e consultas. Também não há compensação financeira relacionada à sua participação. Se existir qualquer despesa adicional, ela será absorvida pelo orçamento da pesquisa. Compromisso do pesquisador de utilizar os dados e o material coletado somente para esta pesquisa.

\section{HOSPITAL DAS CLÍNICAS DA FACULDADE DE MEDICINA DA UNIVERSIDAdE DE SÃO PAULO-HCFMUSP}

Acredito ter sido suficientemente informado a respeito das informações que li ou que foram lidas para mim, descrevendo o estudo "Tratamento das lesões de edema medular ósseo do joelho pela técnica de Subcondroplastia"

Eu discuti com o Dr. Marco Kawamura Demange sobre a minha decisão em participar nesse estudo. Ficaram claros para mim quais são os propósitos do estudo, os procedimentos a serem realizados, seus desconfortos e riscos, as garantias de confidencialidade e de esclarecimentos permanentes. Ficou claro também que minha participação é isenta de despesas e que tenho garantia do acesso a tratamento hospitalar quando necessário. Concordo voluntariamente em participar deste estudo e poderei retirar o meu consentimento a qualquer momento, antes ou durante o mesmo, sem penalidades ou prejuízo ou perda de qualquer beneficio que eu possa ter adquirido, ou no meu atendimento neste Serviço.

Assinatura do paciente/representante legal Data

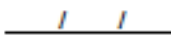

Assinatura da testemunha

Data

para casos de pacientes menores de 18 anos, analfabetos, semi-analfabetos ou portadores de deficiência auditiva ou visual.

\section{(Somente para o responsável do projeto)}

Declaro que obtive de forma apropriada e voluntária o Consentimento Livre e Esclarecido deste paciente ou representante legal para a participaçäo neste estudo. 
Anexo 3 - Parâmetros de aquisição da ressonância magnética

\begin{tabular}{|l|c|c|c|c|c|c|c|c|c|c|}
\hline $\begin{array}{c}\text { Sequência/ } \\
\text { Parâmetro }\end{array}$ & TE & TR & ET & BW & Freq. & Fase & NEX & FOV & Espaçamento & $\begin{array}{c}\text { Espessura } \\
\text { de corte }\end{array}$ \\
\hline Coronal T1 & $\begin{array}{c}\text { Min } \\
\text { Full }\end{array}$ & $400-600$ & 4 & 41,67 & 320 & 192 & 2 & 17,0 & 0,6 & 3,0 \\
\hline Axial T2 FS & 45,0 & $3000-5000$ & 12 & 31,25 & 288 & 192 & 2 & 16,0 & 0,6 & 3,0 \\
\hline Sagital T2 FS & 45,0 & $3000-5000$ & 12 & 31,25 & 320 & 224 & 2 & 17,0 & 0,5 & 3,5 \\
\hline Coronal T2 FS & 45,0 & $3200-5000$ & 12 & 31,25 & 288 & 224 & 2 & 17,0 & 0,6 & 3,5 \\
\hline Sagital T2 & 45,0 & $3000-5000$ & 12 & 31,25 & 320 & 224 & 2 & 17,0 & 0,5 & 3,5 \\
\hline
\end{tabular}


Anexo 4 - Questionário Injury and Osteoarthritis Outcomes Score (KOOS)

\section{QUESTIONÁRIO KOOS SOBRE O JOELHO}

Data:

Data de nascimento: 1

Nome:

INSTRUÇÕES: Este questionário pretende saber como vê o seu joelho. Esta informação dar-nos-á dados sobre como se sente em relação ao joelho e até que ponto é que é capaz de desempenhar as suas actividades normais.

Responda a cada uma das perguntas marcando o quadrado adequado, apenas um quadrado para cada pergunta. Se não tiver a certeza sobre a resposta a escolher, por favor escolha a que achar melhor.

\section{Sintomas}

Estas perguntas devem ser respondidas tendo em conta os sintomas no seu joelho durante a última semana.

S1. Tem tido o joelho inchado?

Nunca Raramente

$$
\text { Ass vezes Frequentemente Sempre }
$$

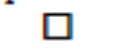

$\square$

S2. Tem sentido ranger, ouvido um estalo ou qualquer outro som quando mexe $\circ$ joelho?

$\begin{array}{ccccc}\text { Nunca } & \text { Raramente } & \text { Ás vezes } & \text { Frequentemente } & \text { Sempre } \\ \square & \square & \square & \square & \square\end{array}$

S3. Tem sentido o joelho preso ou bloqueado quando se mexe?

$\begin{array}{ccccc}\text { Nunca } & \text { Raramente } & \text { As vezes } & \text { Frequentemente } & \text { Sempre } \\ \square & \square & \square & \square & \square\end{array}$

S4. Tem conseguido esticar o joelho completamente?

$\begin{array}{ccccc}\text { Sempre } & \text { Frequentemente } & \text { As vezes } & \text { Raramente } & \text { Nunca } \\ \square & \square & \square & \square & \square\end{array}$

S5. Tem conseguido dobrar o joelho completamente?

Sempre Frequentemente As vezes Raramente Nunca

\section{Rigidez}

As perguntas que se seguem dizem respeito ao grau de rigidez no joelho que teve na última semana. Rigidez é uma sensação de dificuldade ou lentidão a mexer o seu joelho.

S6. Até que ponto sente rigidez no joelho logo após acordar de manhã?
Nada
Pouco
Moderadamente
Muito
Muitíssimo

S7. Até que ponto sente rigidez no joelho depois de se sentar, deitar ou descansar ao fim do dia?
Nada
Pouco
Moderadamente
Muito
Muitissimo 
Dor

P1. Com que frequência tem dores no joelho?

$\begin{array}{ccccc}\text { Nunca } & \text { Uma vez por mês } & \text { Uma vez por semana } & \text { Todos os dias } & \text { Sempre } \\ \square & \square & \square & \square & \square\end{array}$

Que intensidade de dor no joelho é que teve durante a última semana nas seguintes actividades?

P2. Rodar/virar-se/torcer sobre o joelho

$\begin{array}{ccccc}\text { Nenhuma } & \text { Pouca } & \text { Moderada } & \text { Muita } & \text { Muitissima } \\ \square & \square & \square & \square & \square\end{array}$

P3. Esticar o joelho completamente

$\begin{array}{ccccc}\text { Nenhuma } & \text { Pouca } & \text { Moderada } & \text { Muita } & \text { Muitíssima } \\ \square & \square & \square & \square & \square\end{array}$

P4. Dobrar o joelho completamente

$\begin{array}{ccccc}\text { Nenhuma } & \text { Pouca } & \text { Moderada } & \text { Muita } & \text { Muitíssima } \\ \square & \square & \square & \square & \square\end{array}$

P5. Andar sobre uma superficie plana

$\begin{array}{ccccc}\text { Nenhuma } & \text { Pouca } & \text { Moderada } & \text { Muita } & \text { Muitissima } \\ \square & \square & \square & \square & \square\end{array}$

P6. Subir ou descer escadas

Nenhuma Pouca

Muita Muitissima

P7. À noite, na cama

Nenhuma Pouca

$\square \quad \square$

Moderada

$\square$

Muita

Muitissima

P8. Estar sentado/a ou deitado/a

$\begin{array}{ccccc}\text { Nenhuma } & \text { Pouca } & \text { Moderada } & \text { Muita } & \text { Muitíssima } \\ \square & \square & \square & \square & \square \\ \text { Estar de pé } & & & & \\ \begin{array}{c}\text { Nenhuma } \\ \square\end{array} & \text { Pouca } & \text { Moderada } & \text { Muita } & \text { Muitissima } \\ & \square & \square & \square & \square\end{array}$

Actividades da vida diária

As perguntas que se seguem dizem respeito à sua função física. Por função

física referimo-nos à sua capacidade de se deslocar e de cuidar de si. Para cada uma das actividades seguintes, indique o grau de dificuldade que sentiu na última semana por causa do seu joelho.

A1. Descer escadas

Nenhuma

Pouca

Moderada

Muita

Muitíssima

A2. Subir escadas

Nenhuma

Pouca

Moderada

Muita

Muitíssima

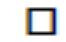

$\square$

$\square$

$\square$

$\square$ 
Para cada uma das seguintes actividades indique, por favor, o grau de dificuldade que teve na última semana devido ao seu joelho.

A3. Levantar-se a partir da posição de sentado/a Nenhuma Pouca Moderada $\square$

$\square$

Muita

Muitissima

A4. Manter-se de pé Nenhuma

Pouca

Moderada

Muita

Muitissima

A5. Dobrar-se para baixo/apanhar um objecto Nenhuma Pouca Moderada $\square$ $\square$ $\square$

Muita Muitissima

A6. Andar numa superficie plana Nenhuma Pouca $\square$

$\square$

Moderada

口

Muita

Muitissima

A7. Entrar ou sair do carro

Nenhuma

Pouca

$\square$

$\square$

Moderada

$\square$

A8. Ir às compras

Nenhuma

Pouca

$\square$

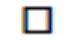

Moderada

Muita

口

Pouca

Nenhuma

$\square$

A10. Levantar-se da cama Nenhuma Pouca

口

Muita

$\square$

$\square$
Moderada

Moderada

Muita

Muita

口

Moderada

Muita

$\square$
Muitissima

$\square$

Muitissima

$\square$

Muitissima

A11. Descalçar meias/collants

Nenhuma Pouca

$\square$

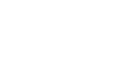

Muitissima

A12. Estar deitado/a na cama (virar-se, manter a posição do joelho)
Nenhuma

Muitissima $\square$

$\square$

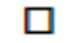

$\square$

A13. Entrar/sair da banheira

Nenhuma

Pouca

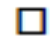

Moderada

Muita

Muitissima

A14. Estar sentado/a

Nenhuma

Pouca

ㅁ

$\square$

$\square \quad \square$

Moderada

Muita

$\square$

$\square$

Muitissima

A15. Sentar-se ou levantar-se da sanita

Nenhuma

$\square$
Pouca

$\square$
Moderada

$\square$

Muita

Muitissima 
Para cada uma das actividades seguintes, indique o grau de dificuldade que sentiu na última semana por causa do seu joelho.

A16. Tarefas domésticas pesadas (ex.: pegar em caixas pesadas, esfregar o chão, etc.)

$\begin{array}{ccccc}\text { Nenhuma } & \text { Pouca } & \text { Moderada } & \text { Muita } & \text { Muitissima } \\ \square & \square & \square & \square & \square\end{array}$

A17. Tarefas domésticas leves (ex.: cozinhar, limpar o pó, etc.)

Nenhuma Pouca $\quad$ Moderada $\quad$ Muita

$\begin{array}{llll}\square & \square & \square\end{array}$

\section{Actividades desportivas e de lazer}

As perguntas que se seguem dizem respeito à sua função física, estando activo/a a um nivel mais elevado. As perguntas devem ser respondidas tendo em conta o grau de dificuldade que teve durante a última semana por causa do seu joelho.

\begin{tabular}{|c|c|c|c|c|}
\hline \multicolumn{5}{|c|}{ SP1. Pôr-se de cócoras } \\
\hline $\begin{array}{c}\text { Nenhuma } \\
\square\end{array}$ & $\begin{array}{c}\text { Pouca } \\
\square\end{array}$ & $\begin{array}{c}\text { Moderada } \\
\square\end{array}$ & $\begin{array}{c}\text { Muita } \\
\square\end{array}$ & $\begin{array}{c}\text { Muitíssima } \\
\square\end{array}$ \\
\hline $\begin{array}{c}\text { SP2. Correr } \\
\text { Nenhuma } \\
\square\end{array}$ & $\begin{array}{c}\text { Pouca } \\
\square\end{array}$ & $\begin{array}{c}\text { Moderada } \\
\square\end{array}$ & $\begin{array}{c}\text { Muita } \\
\square\end{array}$ & $\begin{array}{c}\text { Muitíssima } \\
\square\end{array}$ \\
\hline $\begin{array}{c}\text { SP3. Saltar } \\
\text { Nenhuma } \\
\square\end{array}$ & $\begin{array}{c}\text { Pouca } \\
\square\end{array}$ & $\begin{array}{c}\text { Moderada } \\
\square\end{array}$ & $\begin{array}{c}\text { Muita } \\
\square\end{array}$ & $\begin{array}{c}\text { Muitíssima } \\
\square\end{array}$ \\
\hline $\begin{array}{c}\text { SP4. Rodar/v } \\
\text { Nenhuma } \\
\square\end{array}$ & $\begin{array}{c}\text { rcer so } \\
\text { Pouca } \\
\square\end{array}$ & $\begin{array}{c}\text { ho afectadc } \\
\text { Moderada } \\
\square\end{array}$ & $\begin{array}{c}\text { Muita } \\
\square\end{array}$ & $\begin{array}{c}\text { Muitíssima } \\
\square\end{array}$ \\
\hline $\begin{array}{c}\text { SP5. Ajoelha } \\
\text { Nenhuma } \\
\square\end{array}$ & $\begin{array}{c}\text { Pouca } \\
\square\end{array}$ & $\begin{array}{c}\text { Moderada } \\
\square\end{array}$ & $\begin{array}{c}\text { Muita } \\
\square\end{array}$ & $\begin{array}{c}\text { Muitíssima } \\
\square\end{array}$ \\
\hline
\end{tabular}

\section{Qualidade de Vida}

Q1. Com que frequência é que tem consciência do problema que tem no joelho? Nunca Uma vez por mês Uma vez por semana Todos os dias Constantemente

Q2. Modificou o seu estilo de vida para evitar actividades que poderiam afectar o joelho?

De modo algum Um pouco Moderadamente Muito Completamente

Q3. Até que ponto é que a falta de confiança no joelho o/a incomoda? Nada Um pouco Moderadamente Muito Muitíssimo

Q4. Em geral, o joelho causa-lhe muitos problemas?
Nenhuns
Poucos
Alguns
Muitos
Muitissimos

$\square$

$\square$

口 $\square$


Anexo 5 - Questionário International Knee Documentation Commitee (IKDC) Avaliação Subjetiva IKDC 2000

Nome:

RGHC: TEL: Médico:

Data de hoje: Idade atual: Joelho: Dir/Esc

Data da lesão: Data da cirurgia: I

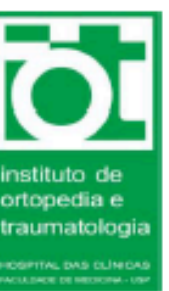

Cirurgia

Sintomas*:

*Marque os sintomas no nivel de atividade mais alto que você acredite que possa realizar sem sintomas significantes, mesmo se você não esteja, de fato, realizando-as neste nivel.

1. Qual o nível mais alto de atividade você conseguiu realizar sem dor significante no joelho?

a Atividades muito exigentes (desgastantes) como saltar ou esportes com movimentos torcionais como basquete ou futebol

口. Atividades exigentes (desgastantes) como trabalho físico pesado esquiar ou jogar tênis

a Atividades moderadas como trabalho físico moderado, corrida ou "Cooper" (jogging).

- Atividades leves como andar, trabalho de casa ou no quintal, jardim.

a Incapaz de realizar qualquer outra atividade devido à dor no joelho

2. Durante ás ultimas 4 semanas, ou desde a sua lesão, com que frequiência você sente dor?
Nunca
$\begin{array}{ll}\mathbf{0} & \mathbf{1} \\ 0 & \mathbf{9}\end{array}$
$\begin{array}{lll}2 & 3 & 4 \\ \square & 0\end{array}$
$\begin{array}{ll}4 & 5 \\ \text { 口 } & \square\end{array}$
$\begin{array}{llllr}6 & 7 & 8 & 9 & 10 \\ \text { 口 } & \square & \square & \square & \square\end{array}$
Constantemente

3. Se você tem dor, qual a intensidade dessa dor?
Sem dor
$\begin{array}{ll}\mathbf{0} & \mathbf{1} \\ \mathrm{a} & \mathrm{a}\end{array}$
$\begin{array}{ll}2 & 3 \\ \square & \square\end{array}$
4
व
$\begin{array}{llllll}5 & 6 & 7 & 8 & 9 & 10 \\ \text { 口 } & \square & \square & \square & 9 & 0\end{array}$
Pior dor Sentida

4. Durante ás ultimas 4 semanas, ou desde a sua lesão, com que intensidade seu joelho ficou rígido (endurecido) inchado?
व Não Ficou
L Levemente
a Moderadamente
Muito
口 Extremamente

5. Qual o nível mais alto de atividade que você pode realizarem inchar (edemaciar) o seu joelho?

a Atividades muito exigentes (desgastantes) como saltar ou esportes com movimentos torcionais como basquete ou futebol

口 Atividades exigentes (desgastantes) como trabalho fisico pesado esquiar ou jogar tênis

a Atividades moderadas como trabalho físico moderado, corrida ou "Cooper" (jogging).

a Atividades leves como andar, trabalho de casa ou no quintal, jardim.

a Incapaz de realizar qualquer outra atividade devido à dor no joelho

6. Durante ás ultimas 4 semanas, ou desde a sua lesão, seu joelho travou ou teve a sensacão de ficar preso?
口 Sim
ם Não 
7. Qual é o nivel de atividade mais alto que você pode realizar sem sentir um "falseio" ou falha significante em seu joelho?

a Atividades muito exigentes (desgastantes) como saltar ou esportes com movimentos torcionais como basquete ou futebol

a Atividades exigentes (desgastantes) como trabalho físico pesado esquiar ou jogar tênis

a Atividades moderadas como trabalho físico moderado, corrida ou "Cooper" (jogging).

a Atividades leves como andar, trabalho de casa ou no quintal, jardim.

口 Incapaz de realizar qualquer outra atividade devido à dor no joelho

\section{ATIVIDADE NO ESPORTE:}

8. Qual o nível de atividade mais alto que você pode realizar numa frequiência regular?
a Atividades muito exigentes (desgastantes) como saltar ou esportes com movimentos torcionais como basquete ou futebol
- Atividades exigentes (desgastantes) como trabalho físico pesado esquiar ou jogar tênis
a Atividades moderadas como trabalho físico moderado, corrida ou "Cooper" (jogging).
a Atividades leves como andar, trabalho de casa ou no quintal, jardim.
- Incapaz de realizar qualquer outra atividade devido à dor no joelho

9. Quanto o seu joelho afeta sua habilidade de:

\begin{tabular}{l|l|c|c|c|c|c|}
\hline & $\begin{array}{c}\text { Nenhuma } \\
\text { dificuldade }\end{array}$ & $\begin{array}{c}\text { Dificuldade } \\
\text { mínima }\end{array}$ & $\begin{array}{c}\text { Dificuldade } \\
\text { moderada }\end{array}$ & $\begin{array}{c}\text { Dificuldade } \\
\text { Extrema }\end{array}$ & $\begin{array}{c}\text { Incapaz } \\
\text { de } \\
\text { Realizar }\end{array}$ \\
\hline A. & Subir escadas & $\square$ & $\square$ & $\square$ & $\square$ & $\square$ \\
\hline B. & Descer escadas & $\square$ & $\square$ & $\square$ & $\square$ & $\square$ \\
\hline C. & Ajoelhar-se & $\square$ & $\square$ & $\square$ & $\square$ & $\square$ \\
\hline D. & Agachamento & $\square$ & $\square$ & $\square$ & $\square$ & $\square$ \\
\hline E. & Sentar com seu joelho dobrado & $\square$ & $\square$ & $\square$ & $\square$ & $\square$ \\
\hline F. & Subir numa cadeira & $\square$ & $\square$ & $\square$ & $\square$ & $\square$ \\
\hline G. & Correr em linha reta & $\square$ & $\square$ & $\square$ & $\square$ & $\square$ \\
\hline H. & $\begin{array}{l}\text { Saltar e cair sobre a perna } \\
\text { envolvida }\end{array}$ & $\square$ & $\square$ & $\square$ & $\square$ & $\square$ \\
\hline I. & Parar e reiniciar rapidamente & $\square$ & $\square$ & $\square$ & $\square$ & $\square$ \\
\hline
\end{tabular}

\section{FUNCÃ̃o:}

Que nota para a função do seu joelho numa escala de $\mathbf{0}$ a 10, sendo 10 função normal, excelente e 0 incapacidade de realizar qualquer das atividades usuais do seu dia-a-dia?

\section{FUNÇÃO ANIES DE SUA LESÃO NO JOELHO:}

$\begin{array}{lllllllllllll}\begin{array}{l}\text { Não pode } \\ \text { realizar } \\ \text { atividades de }\end{array} & 0 & 1 & 2 & 3 & 4 & 5 & 6 & 7 & 8 & 9 & 10 & \\ \text { vida } & \square & \square & \square & \square & \square & \square & \square & \square & \square & \square & \text { Sem limitacões }\end{array}$

vida diária

FUNÇÃO ATUAL DO SEU JOELHO:

\begin{tabular}{lllllllllllll}
$\begin{array}{l}\text { Não pode } \\
\text { realizar } \\
\text { atividades de } \\
\text { vida diária }\end{array}$ & 0 & 1 & 2 & 3 & 4 & 5 & 6 & 7 & 8 & 9 & 10 & \\
\hline & $\square$ & $\square$ & $\square$ & $\square$ & $\square$ & $\square$ & $\square$ & $\square$ & $\square$ & $\square$ & Sem limitacóes
\end{tabular}


Anexo 6 - Questionário Qualidade de Vida SF-36v1

\section{Versão Brasileira do Questionário de Qualidade de Vida -SF-36}

1- Em geral você diria que sua saúde é:

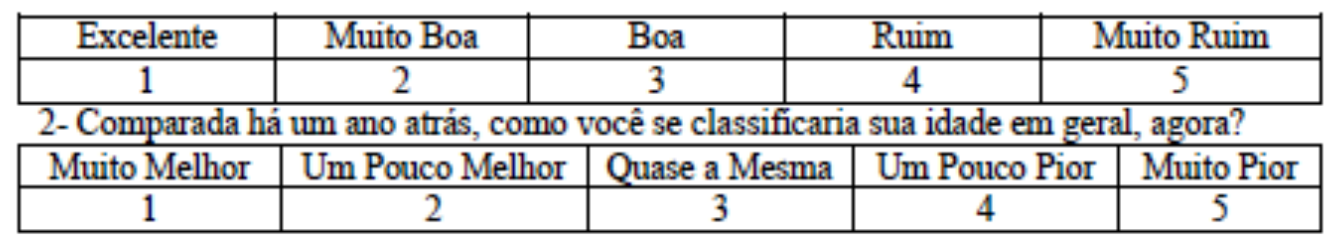

3- Os seguintes itens são sobre atividades que você poderia fazer atualmente durante um dia comum. Devido à sua saúde, você teria dificuldade para fazer estas atividades? Neste caso, quando?

\begin{tabular}{|l|c|c|c|}
\hline \multicolumn{1}{|c|}{ Atividades } & $\begin{array}{c}\text { Sim, dificulta } \\
\text { muito }\end{array}$ & $\begin{array}{c}\text { Sim, dificulta } \\
\text { um pouco }\end{array}$ & $\begin{array}{c}\text { Não, não } \\
\text { dificulta de } \\
\text { modo algum }\end{array}$ \\
\hline $\begin{array}{l}\text { a) Atividades Rigorosas, que exigem } \\
\text { muito esforço, tais como correr, } \\
\text { levantar objetos pesados, participar em } \\
\text { esportes árduos. }\end{array}$ & 1 & 2 & 3 \\
\hline $\begin{array}{l}\text { b) Atividades moderadas, tais como } \\
\text { mover uma mesa, passar aspirador de } \\
\text { pó, jogar bola, varrer a casa. }\end{array}$ & 1 & 2 & 3 \\
\hline c) Levantar ou carregar mantimentos & 1 & 2 & 3 \\
\hline d) Subir vários lances de escada & 1 & 2 & 3 \\
\hline e) Subir um lance de escada & 1 & 2 & 3 \\
\hline $\begin{array}{l}\text { f) Curvar-se, ajoelhar-se ou dobrar- } \\
\text { se }\end{array}$ & 1 & 2 & 3 \\
\hline g) Andar mais de 1 quilômetro & 1 & 2 & 3 \\
\hline h) Andar vários quarteirões & 1 & 2 & 3 \\
\hline i) Andar um quarteirão & 1 & 2 & 3 \\
\hline j) Tomar banho ou vestir-se & 1 & 2 & 3 \\
\hline
\end{tabular}

4-Durante as últimas 4 semanas, você teve algum dos seguintes problemas com seu trabalho ou com alguma atividade regular, como consequêencia de sua saúde fisica?

\begin{tabular}{|l|c|c|}
\hline & Sim & Não \\
\hline $\begin{array}{l}\text { a) Você diminui a quantidade de tempo que se dedicava ao seu } \\
\text { trabalho ou a outras atividades? }\end{array}$ & 1 & 2 \\
\hline b) Realizou menos tarefas do que você gostaria? & 1 & 2 \\
\hline c) Esteve limitado no seu tipo de trabalho ou a outras atividades. & 1 & 2 \\
\hline $\begin{array}{l}\text { d) Teve dificuldade de fazer seu trabalho ou outras atividades (p. } \\
\text { ex. necessitou de um esforço extra). }\end{array}$ & 1 & 2 \\
\hline
\end{tabular}

5-Durante as últimas 4 semanas, você teve algum dos seguintes problemas com seu trabalho ou outra atividade regular diária, como consequiência de algum problema emocional (como se sentir deprimido ou ansioso)?

\begin{tabular}{|l|c|c|}
\hline $\begin{array}{l}\text { a) Você diminui a quantidade de tempo que se dedicava ao seu } \\
\text { trabalho ou a outras atividades? }\end{array}$ & 1 & Não \\
\hline b) Realizou menos tarefas do que você gostaria? & 1 & 2 \\
\hline $\begin{array}{l}\text { c) Não realizou ou fez qualquer das atividades com tanto cuidado } \\
\text { como geralmente faz. }\end{array}$ & 1 & 2 \\
\hline
\end{tabular}


6- Durante as últimas 4 semanas, de que maneira sua saúde fisica ou problemas emocionais interferiram nas suas atividades sociais normais, em relação à familia, amigos ou em grupo?

\begin{tabular}{|c|c|c|c|c|}
\hline De forma nenhuma & Ligeiramente & Moderadamente & Bastante & Extremamente \\
\hline 1 & 2 & 3 & 4 & 5 \\
\hline
\end{tabular}

7- Quanta dor no corpo você teve durante as últimas 4 semanas?

\begin{tabular}{|c|c|c|c|c|c|}
\hline Nenhuma & Muito leve & Leve & Moderada & Grave & Muito grave \\
\hline 1 & 2 & 3 & 4 & 5 & 6 \\
\hline
\end{tabular}

8- Durante as últimas 4 semanas, quanto a dor interferiu com seu trabalho normal (incluindo o trabalho dentro de casa)?

\begin{tabular}{|c|c|c|c|c|}
\hline De maneira alguma & Um pouco & Moderadamente & Bastante & Extremamente \\
\hline 1 & 2 & 3 & 4 & 5 \\
\hline
\end{tabular}

9- Estas questões são sobre como você se sente e como tudo tem acontecido com você durante as últimas 4 semanas. Para cada questão, por favor dê uma resposta que mais se aproxime de maneira como você se sente, em relação às últimas 4 semanas.

\begin{tabular}{|l|c|c|c|c|c|c|}
\hline & $\begin{array}{c}\text { Todo } \\
\text { Tempo }\end{array}$ & $\begin{array}{c}\text { A maior } \\
\text { parte do } \\
\text { tempo }\end{array}$ & $\begin{array}{c}\text { Uma boa } \\
\text { parte do } \\
\text { tempo }\end{array}$ & $\begin{array}{c}\text { Alguma } \\
\text { parte do } \\
\text { tempo }\end{array}$ & $\begin{array}{c}\text { Uma } \\
\text { pequena } \\
\text { parte do } \\
\text { tempo }\end{array}$ & Nunca \\
\hline $\begin{array}{l}\text { a) Quanto tempo você } \\
\text { tem se sentindo cheio de } \\
\text { vigor, de vontade, de } \\
\text { força? }\end{array}$ & 1 & 2 & 3 & 4 & 5 & 6 \\
\hline $\begin{array}{l}\text { b) Quanto tempo você } \\
\text { tem se sentido uma } \\
\text { pessoa muito nervosa? }\end{array}$ & 1 & 2 & 3 & 4 & 5 & 6 \\
\hline $\begin{array}{l}\text { c) Quanto tempo você } \\
\text { tem se sentido tâo } \\
\text { deprimido que nada } \\
\text { pode anima-lo? }\end{array}$ & 1 & 2 & 3 & 4 & 5 & 6 \\
\hline $\begin{array}{l}\text { d) Quanto tempo você } \\
\text { tem se sentido calmo ou } \\
\text { tranqüilo? }\end{array}$ & 1 & 2 & 3 & 4 & 5 & 6 \\
\hline $\begin{array}{l}\text { e) Quanto tempo você } \\
\text { tem se sentido com } \\
\text { muita energia? }\end{array}$ & 1 & 2 & 3 & 4 & 5 & 6 \\
\hline $\begin{array}{l}\text { f) Quanto tempo você } \\
\text { tem se sentido } \\
\text { desanimado ou abatido? }\end{array}$ & 1 & 2 & 3 & 4 & 5 & 6 \\
\hline $\begin{array}{l}\text { g) Quanto tempo você } \\
\text { tem se sentido } \\
\text { esgotado? }\end{array}$ & 1 & 2 & 3 & 4 & 5 & 6 \\
\hline $\begin{array}{l}\text { h) Quanto tempo você } \\
\text { tem se sentido uma } \\
\text { pessoa feliz? }\end{array}$ & 1 & 2 & 3 & 4 & 5 & 6 \\
\hline $\begin{array}{l}\text { i) Quanto tempo você } \\
\text { tem se sentido cansado? }\end{array}$ & 1 & 2 & 3 & 4 & 5 & 6 \\
\hline
\end{tabular}


10- Durante as últimas 4 semanas, quanto de seu tempo a sua saúde física ou problemas emocionais interferiram com as suas atividades sociais (como visitar amigos, parentes, etc)?

\begin{tabular}{|c|c|c|c|c|}
\hline $\begin{array}{c}\text { Todo } \\
\text { Tempo }\end{array}$ & $\begin{array}{c}\text { A maior parte do } \\
\text { tempo }\end{array}$ & $\begin{array}{c}\text { Alguma parte do } \\
\text { tempo }\end{array}$ & $\begin{array}{c}\text { Uma pequena } \\
\text { parte do tempo }\end{array}$ & $\begin{array}{c}\text { Nenhuma parte } \\
\text { do tempo }\end{array}$ \\
\hline 1 & 2 & 3 & 4 & 5 \\
\hline
\end{tabular}

11- O quanto verdadeiro ou falso é cada uma das afirmações para você?

\begin{tabular}{|l|c|c|c|c|c|}
\hline & $\begin{array}{c}\text { Definitivamente } \\
\text { verdadeiro }\end{array}$ & $\begin{array}{c}\text { A maioria } \\
\text { das vezes } \\
\text { verdadeiro }\end{array}$ & $\begin{array}{c}\text { Não } \\
\text { sei }\end{array}$ & $\begin{array}{c}\text { A maioria } \\
\text { das vezes } \\
\text { falso }\end{array}$ & $\begin{array}{c}\text { Definitiva- } \\
\text { mente falso }\end{array}$ \\
\hline $\begin{array}{l}\text { a) Eu costumo obedecer } \\
\text { um pouco mais } \\
\text { facilmente que as outras } \\
\text { pessoas }\end{array}$ & 1 & 2 & 3 & 4 & 5 \\
\hline $\begin{array}{l}\text { b) Eu sou tão saudável } \\
\text { quanto qualquer pessoa } \\
\text { que eu conheço }\end{array}$ & 1 & 2 & 3 & 4 & 5 \\
\hline $\begin{array}{l}\text { c) Eu acho que a minha } \\
\text { saúde vai piorar }\end{array}$ & 1 & 2 & 3 & 4 & 5 \\
\hline $\begin{array}{l}\text { d) Minha saúde é } \\
\text { excelente }\end{array}$ & 1 & 2 & 3 & 4 & 5 \\
\hline
\end{tabular}

\section{REFERÊNCIAS}

1. Gil HC, Levine SM and Zoga AC. MRI findings in the subchondral bone marrow: a discussion of conditions including transient osteoporosis, transient bone marrow edema syndrome, SONK, and shifting bone marrow edema of the knee. Seminars in musculoskeletal radiology. $\quad$ 2006; 10: 177-86.

2. Kon E, Ronga M, Filardo G, et al. Bone marrow lesions and subchondral bone pathology of the knee. Knee surgery, sports traumatology, arthroscopy: official journal of the ESSKA. 2016; 24: 1797-814.

3. Manara M and Varenna M. A clinical overview of bone marrow edema. Reumatismo. 2014; 66: 184-96.

4. Wilson AJ, Murphy WA, Hardy DC and Totty WG. Transient osteoporosis: transient bone marrow edema? Radiology. 1988; 167: 757-60.

5. Zanetti M, Bruder E, Romero J and Hodler J. Bone marrow edema pattern in osteoarthritic knees: correlation between MR imaging and histologic findings. Radiology. 2000; 215: 835-40.

6. Collins J, Beutel B, Bosco J, Strauss E, Youm T and Jazrawi L. Bone Marrow Edema: Chronic Bone Marrow Lesions of the Knee and the Association with Osteoarthritis. Bull Hosp Jt Dis (2013). 2016; 74: 24-36.

7. Fowkes LA and Toms AP. Bone marrow oedema of the knee. The Knee. 2010; 17: 1-6.

8. Hofmann S, Kramer J, Vakil-Adli A, Aigner N and Breitenseher M. Painful bone marrow edema of the knee: differential diagnosis and therapeutic concepts. Orthop Clin North Am. $\quad$ 2004; 35: 321-33, ix. 
9. Roemer FW, Frobell R, Hunter DJ, et al. MRI-detected subchondral bone marrow signal alterations of the knee joint: terminology, imaging appearance, relevance and radiological differential diagnosis. Osteoarthritis and cartilage / OARS, Osteoarthritis Research Society. 2009; 17: 1115-31.

10. Baranyay FJ, Wang Y, Wluka AE, et al. Association of bone marrow lesions with knee structures and risk factors for bone marrow lesions in the knees of clinically healthy, community-based adults. Seminars in arthritis and rheumatism. 2007; 37: 112-8.

11. Davies-Tuck ML, Wluka AE, Wang Y, English DR, Giles GG and Cicuttini F. The natural history of bone marrow lesions in community-based adults with no clinical knee osteoarthritis. Annals of the rheumatic diseases. 2009; 68: 904-8. 12. Dore D, Quinn S, Ding C, et al. Natural history and clinical significance of MRI-detected bone marrow lesions at the knee: a prospective study in community dwelling older adults. Arthritis research \& therapy. 2010; 12: R223. 13. Englund M, Guermazi A, Roemer FW, et al. Meniscal pathology on MRI increases the risk for both incident and enlarging subchondral bone marrow lesions of the knee: the MOST Study. Annals of the rheumatic diseases. 2010; 69: 1796-802.

14. Felson DT, Chaisson CE, Hill CL, et al. The association of bone marrow lesions with pain in knee osteoarthritis. Annals of internal medicine. $\quad 2001$; 134: 541-9.

15. Felson DT, McLaughlin S, Goggins J, et al. Bone marrow edema and its relation to progression of knee osteoarthritis. Annals of internal medicine. 2003; 139: 330-6.

16. Felson DT, Niu J, Guermazi A, et al. Correlation of the development of knee pain with enlarging bone marrow lesions on magnetic resonance imaging. Arthritis and rheumatism. 2007; 56: 2986-92.

17. Guymer E, Baranyay F, Wluka AE, et al. A study of the prevalence and associations of subchondral bone marrow lesions in the knees of healthy, middle-aged women. Osteoarthritis and cartilage / OARS, Osteoarthritis Research Society. 2007; 15: 1437-42.

18. Hunter DJ, Zhang Y, Niu J, et al. Increase in bone marrow lesions associated with cartilage loss: a longitudinal magnetic resonance imaging study of knee osteoarthritis. Arthritis and rheumatism. 2006; 54: 1529-35.

19. Kijowski R, Stanton P, Fine J and De Smet A. Subchondral bone marrow edema in patients with degeneration of the articular cartilage of the knee joint. Radiology. 2006; 238: 943-9.

20. Lim YZ, Wang Y, Wluka AE, et al. Association of obesity and systemic factors with bone marrow lesions at the knee: a systematic review. Seminars in arthritis and rheumatism. 2014; 43: 600-12.

21. Lim YZ, Wang Y, Wluka AE, et al. Are biomechanical factors, meniscal pathology, and physical activity risk factors for bone marrow lesions at the knee? A systematic review. Seminars in arthritis and rheumatism. 2013; 43: 187-94. 22. Lo GH, Hunter DJ, Zhang Y, et al. Bone marrow lesions in the knee are associated with increased local bone density. Arthritis and rheumatism. 2005; 52: 2814-21.

23. Raynauld JP, Martel-Pelletier J, Berthiaume MJ, et al. Correlation between bone lesion changes and cartilage volume loss in patients with osteoarthritis of 
the knee as assessed by quantitative magnetic resonance imaging over a 24month period. Annals of the rheumatic diseases. 2008; 67: 683-8.

24. Roemer FW, Guermazi A, Javaid MK, et al. Change in MRI-detected subchondral bone marrow lesions is associated with cartilage loss: the MOST Study. A longitudinal multicentre study of knee osteoarthritis. Annals of the rheumatic diseases. 2009; 68: 1461-5.

25. Roemer FW, Neogi T, Nevitt MC, et al. Subchondral bone marrow lesions are highly associated with, and predict subchondral bone attrition longitudinally: the MOST study. Osteoarthritis and cartilage / OARS, Osteoarthritis Research Society. 2010; 18: 47-53.

26. Scher C, Craig J and Nelson F. Bone marrow edema in the knee in osteoarthrosis and association with total knee arthroplasty within a three-year follow-up. Skeletal Radiol. 2008; 37: 609-17.

27. Sowers MF, Hayes C, Jamadar D, et al. Magnetic resonance-detected subchondral bone marrow and cartilage defect characteristics associated with pain and X-ray-defined knee osteoarthritis. Osteoarthritis and cartilage / OARS, Osteoarthritis Research Society. 2003; 11: 387-93.

28. Tanamas SK, Wluka AE, Pelletier J-P, et al. Bone marrow lesions in people with knee osteoarthritis predict progression of disease and joint replacement: a longitudinal study. Rheumatology. 2010; 49: 2413-9.

29. Unay K, Poyanli O, Akan K, Guven M and Demircay C. The relationship between bone marrow edema size and knee pain. Knee surgery, sports traumatology, arthroscopy : official journal of the ESSKA. 2009; 17: 1298-304. 30. Zhao J, Li XJ, Bolbos RI, Link TM and Majumdar S. Longitudinal assessment of bone marrow edema-like lesions and cartilage degeneration in osteoarthritis using 3 T MR T1rho quantification. Skeletal Radiol. $\quad$ 2010; 39: 523-31.

31. Camanho GL. Dor aguda no joelho do paciente idoso. Revista Brasileira de Ortopedia. 2008; 43: 361-6.

32. Plett SK, Hackney LA, Heilmeier U, et al. Femoral condyle insufficiency fractures: associated clinical and morphological findings and impact on outcome. Skeletal Radiol. 2015; 44: 1785-94.

33. Yamamoto T and Bullough PG. Spontaneous osteonecrosis of the knee: the result of subchondral insufficiency fracture. The Journal of bone and joint surgery American volume. $\quad 2000 ; 82: 858-66$.

34. Taljanovic MS, Graham AR, Benjamin JB, et al. Bone marrow edema pattern in advanced hip osteoarthritis: quantitative assessment with magnetic resonance imaging and correlation with clinical examination, radiographic findings, and histopathology. Skeletal Radiol. 2008; 37: 423-31.

35. Yates PJ, Calder JD, Stranks GJ, Conn KS, Peppercorn D and Thomas NP. Early MRI diagnosis and non-surgical management of spontaneous osteonecrosis of the knee. The Knee. 2007; 14: 112-6.

36. Mayerhoefer ME, Kramer J, Breitenseher MJ, et al. MRI-demonstrated outcome of subchondral stress fractures of the knee after treatment with iloprost or tramadol: observations in 14 patients. Clinical journal of sport medicine : official journal of the Canadian Academy of Sport Medicine. 2008; 18: 358-62. 37. Mayerhoefer ME, Kramer J, Breitenseher MJ, et al. Short-term outcome of painful bone marrow oedema of the knee following oral treatment with iloprost 
or tramadol: results of an exploratory phase II study of 41 patients. Rheumatology (Oxford). 2007; 46: 1460-5.

38. Kraenzlin ME, Graf C, Meier C, Kraenzlin C and Friedrich NF. Possible beneficial effect of bisphosphonates in osteonecrosis of the knee. Knee Surg Sports Traumatol Arthrosc. 2010; 18: 1638-44.

39. Meier C, Kraenzlin C, Friederich NF, et al. Effect of ibandronate on spontaneous osteonecrosis of the knee: a randomized, double-blind, placebocontrolled trial. Osteoporos Int. 2014; 25: 359-66.

40. Jager M, Tillmann FP, Thornhill TS, et al. Rationale for prostaglandin I2 in bone marrow oedema--from theory to application. Arthritis Res Ther. 2008; 10: R120.

41. Wilson AJ, Murphy WA, Hardy DC and Totty WG. Transient osteoporosis: transient bone marrow edema? Radiology. 1988; 167: 757-60.

42. Bergman AG, Willen HK, Lindstrand AL and Pettersson HT. Osteoarthritis of the knee: correlation of subchondral MR signal abnormalities with histopathologic and radiographic features. Skeletal Radiol. $\quad$ 1994; 23: 445-8. 43. Koshino T. The treatment of spontaneous osteonecrosis of the knee by high tibial osteotomy with and without bone-grafting or drilling of the lesion. The Journal of bone and joint surgery American volume. 1982; 64: 47-58.

44. Felson DT, McLaughlin S, Goggins J, et al. Bone marrow edema and its relation to progression of knee osteoarthritis. Annals of internal medicine. 2003; 139: 330-6.

45. Kornaat PR, Kloppenburg M, Sharma R, et al. Bone marrow edema-like lesions change in volume in the majority of patients with osteoarthritis; associations with clinical features. Eur Radiol. 2007; 17: 3073-8.

46. Kroner AH, Berger CE, Kluger R, Oberhauser G, Bock P and Engel A. Influence of high tibial osteotomy on bone marrow edema in the knee. Clinical orthopaedics and related research. 2007; 454: 155-62.

47. Hunter DJ, Gerstenfeld L, Bishop G, et al. Bone marrow lesions from osteoarthritis knees are characterized by sclerotic bone that is less well mineralized. Arthritis research \& therapy. $\quad 2009 ; 11$ : R11.

48. Segal NA, Kern AM, Anderson DD, et al. Elevated tibiofemoral articular contact stress predicts risk for bone marrow lesions and cartilage damage at 30 months. Osteoarthritis and cartilage / OARS, Osteoarthritis Research Society. 2012; 20: 1120-6.

49. Kazakia GJ, Kuo D, Schooler J, et al. Bone and cartilage demonstrate changes localized to bone marrow edema-like lesions within osteoarthritic knees. Osteoarthr Cartilage. 2013; 21: 94-101.

50. Ratzlaff C, Guermazi A, Collins J, et al. A rapid, novel method of volumetric assessment of MRI-detected subchondral bone marrow lesions in knee osteoarthritis. Osteoarthritis and cartilage / OARS, Osteoarthritis Research Society. 2013; 21: 806-14.

51. Beckwee D, Vaes P, Shahabpour M, Muyldermans R, Rommers N and Bautmans I. The Influence of Joint Loading on Bone Marrow Lesions in the Knee: A Systematic Review With Meta-analysis. The American journal of sports medicine. 2015; 43: 3093-107.

52. Zhu Z, Jin X, Wang B, et al. Cross-Sectional and Longitudinal Associations Between Serum Levels of High-Sensitivity C-Reactive Protein, Knee Bone 
Marrow Lesions, and Knee Pain in Patients With Knee Osteoarthritis. Arthritis care \& research. 2016; 68: 1471-7.

53. Teichtahl AJ, Cicuttini FM, Abram F, et al. Meniscal extrusion and bone marrow lesions are associated with incident and progressive knee osteoarthritis. Osteoarthritis and cartilage / OARS, Osteoarthritis Research Society. 2017; 25: 1076-83.

54. Hussain ZB, Chahla J, Mandelbaum BR, Gomoll AH and LaPrade RF. The Role of Meniscal Tears in Spontaneous Osteonecrosis of the Knee: A Systematic Review of Suspected Etiology and a Call to Revisit Nomenclature. The American journal of sports medicine. 2019; 47: 501-7.

55. Muratovic D, Findlay DM, Cicuttini FM, Wluka AE, Lee YR and Kuliwaba JS. Bone matrix microdamage and vascular changes characterize bone marrow lesions in the subchondral bone of knee osteoarthritis. Bone. 2018; 108: 193201.

56. Sharkey PF, Cohen SB, Leinberry CF and Parvizi J. Subchondral bone marrow lesions associated with knee osteoarthritis. American journal of orthopedics. 2012; 41: 413-7.

57. Abrams GD, Alentorn-Geli E, Harris JD and Cole BJ. Treatment of a lateral tibial plateau osteochondritis dissecans lesion with subchondral injection of calcium phosphate. Arthroscopy techniques. 2013; 2: e271-4.

58. Farr J and Cohen SB. Expanding Applications of the Subchondroplasty Procedure for the Treatment of Bone Marrow Lesions Observed on Magnetic Resonance Imaging. Oper Techn Sport Med. 2013; 21: 138-43.

59. Chatterjee D, McGee A, Strauss E, Youm T and Jazrawi L. Subchondral Calcium Phosphate is Ineffective for Bone Marrow Edema Lesions in Adults With Advanced Osteoarthritis. Clinical orthopaedics and related research. 2015. 60. Wyland DJ. Letter to the Editor: Subchondral Calcium Phosphate is Ineffective for Bone Marrow Edema Lesions in Adults with Advanced Osteoarthritis. Clinical orthopaedics and related research. 2015.

61. Colon DA, Yoon BJ, Russell TA, Cammisa FP and Abjornson C. Assessment of the injection behavior of commercially available bone BSMs for Subchondroplasty(R) procedures. The Knee. 2015.

62. Cohen SB and Sharkey PF. Subchondroplasty for Treating Bone Marrow Lesions. The journal of knee surgery. 2015.

63. Agten CA, Kaplan DJ, Jazrawi LM and Burke CJ. Subchondroplasty: What the Radiologist Needs to Know. AJR Am J Roentgenol. 2016; 207: 1257-62.

64. Yoo JY, O'Malley MJ, Matsen Ko LJ, Cohen SB and Sharkey PF. Knee Arthroplasty After Subchondroplasty: Early Results, Complications, and Technical Challenges. J Arthroplasty. 2016; 31: 2188-92.

65. Bonadio MB, Giglio PN, Helito CP, Pecora JR, Camanho GL and Demange MK. Subchondroplasty for treating bone marrow lesions in the knee - initial experience. Rev Bras Ortop. 2017; 52: 325-30.

66. Dold A, Perretta D and Youm T. Osteomyelitis After Calcium Phosphate Subchondroplasty A Case Report. Bull Hosp Jt Dis (2013). 2017; 75: 282-5.

67. Astur DC, de Freitas EV, Cabral PB, et al. Evaluation and Management of Subchondral Calcium Phosphate Injection Technique to Treat Bone Marrow Lesion. Cartilage. 2018: 1947603518770249.

68. Bernhard K, Ng A, Kruse D and Stone PA. Surgical Treatment of Bone Marrow Lesion Associated with Recurrent Plantar Fasciitis: A Case Report 
Describing an Innovative Technique Using Subchondroplasty((R)). The Journal of foot and ankle surgery: official publication of the American College of Foot and Ankle Surgeons. 2018; 57: 811-5.

69. Brimmo OA, Bozynski CC, Cook CR, et al. Subchondroplasty for the treatment of post-traumatic bone marrow lesions of the medial femoral condyle in a pre-clinical canine model. Journal of orthopaedic research : official publication of the Orthopaedic Research Society. 2018; 36: 2709-17.

70. Mellier C, Lefevre FX, Fayon F, et al. A straightforward approach to enhance the textural, mechanical and biological properties of injectable calcium phosphate apatitic cements (CPCs): CPC/blood composites, a comprehensive study. Acta biomaterialia. 2017; 62: 328-39.

71. Coker RH, Hays NP, Williams RH, Wolfe RR and Evans WJ. Bed rest promotes reductions in walking speed, functional parameters, and aerobic fitness in older, healthy adults. The journals of gerontology Series A, Biological sciences and medical sciences. 2015; 70: 91-6.

72. Gandhi R, Petruccelli D, Devereaux PJ, Adili A, Hubmann M and de Beer J. Incidence and timing of myocardial infarction after total joint arthroplasty. $J$ Arthroplasty. 2006; 21: 874-7.

73. Mantilla CB, Horlocker TT, Schroeder DR, Berry DJ and Brown DL. Frequency of myocardial infarction, pulmonary embolism, deep venous thrombosis, and death following primary hip or knee arthroplasty.

Anesthesiology. 2002; 96: 1140-6. 